\title{
Microbial food web interactions in two Long Island embayments
}

\author{
Katie Rose Boissonneault-Cellineri ${ }^{1}$, Mausmi Mehta ${ }^{2}$, Darcy J. Lonsdale ${ }^{3}$, \\ David A. Caron ${ }^{4, *}$ \\ ${ }^{1}$ Biology Department, Woods Hole Oceanographic Institution, Woods Hole, Massachusetts 02543, USA \\ ${ }^{2}$ School of Oceanography, University of Washington, Seattle, Washington 98195, USA \\ ${ }^{3}$ Marine Sciences Research Center, SUNY Stony Brook, Stony Brook, New York 11794, USA \\ ${ }^{4}$ Department of Biological Sciences, University of Southern California, 3616 Trousdale Parkway, AHF 301, Los Angeles, \\ California 90089-0371, USA
}

\begin{abstract}
Phytoplankton mortality (herbivory) and bacterivory were examined experimentally in West Neck Bay and Coecles Harbor, Long Island, NY, from April through September 1998. Small algae $(<5 \mu$ m diameter) dominated phytoplankton communities in both ecosystems throughout much of the summer, and most microzooplankton $(<200 \mu \mathrm{m})$ were also small $(<40 \mu \mathrm{m})$ for that category. Generally, plankton abundances were indicative of eutrophic ecosystems. Oscillations in standing stocks and mortality of prey indicated tight coupling of growth and grazing mortality in both bays. Phytoplankton mortality rates accounted for the removal of 14 to $65 \%$ of total phytoplankton standing stocks daily, while bacterivory accounted for the removal of 14 to $88 \%$ of total bacterial standing stocks daily. Carbon consumption was estimated from phytoplankton and bacterial removal rates and from conversion to carbon from chlorophyll (phytoplankton) or cell number (bacteria). These calculations indicated that carbon consumption due to bacterivory constituted an average of 21 and $47 \%$ of carbon consumption due to herbivory in West Neck Bay and Coecles Harbor, respectively. Total carbon consumption (bacterivory + herbivory) revealed high energy flux through the nano- and microzooplankton assemblages of these estuarine environments.
\end{abstract}

KEY WORDS: Bacterivory $\cdot$ Herbivory $\cdot$ Microbial ecology $\cdot$ Bacteria $\cdot$ Phytoplankton $\cdot$ Zooplankton · Protozoa $\cdot$ Long Island Bays $\cdot$ Peconic Bay $\cdot$ Estuary

\section{INTRODUCTION}

The estuarine waters of Long Island, NY, form a complex system of bays characterized by high standing stocks of microbial biomass and high rates of primary productivity (Ryther 1954, Bruno et al. 1980, Lively et al. 1983, Cosper et al. 1989, Nuzzi \& Waters 1989, Lonsdale et al. 1996). Seasonal maxima of chlorophyll concentration in excess of $60 \mu g \mathrm{l}^{-1}$ have been observed in these ecosystems, and rates of production have exceeded $400 \mathrm{mg} \mathrm{C} \mathrm{m}{ }^{-2} \mathrm{~h}^{-1}$ (Cosper et al. 1989,

${ }^{*}$ Corresponding author. E-mail: dcaron@usc.edu
Lonsdale et al. 1996). Maximal rates of primary productivity occur in these well-mixed bays during summer, when high irradiance and high water temperatures favor algal growth.

West Neck Bay (WNB) and Coecles Harbor $(\mathrm{CH})$ form part of the Peconic Estuary System, a group of shallow (average depth $4.7 \mathrm{~m}$ ), strongly mixed, interconnected estuarine ecosystems in eastern Long Island (Hardy 1976, Wilson 1995). Phytoplankton communities in these bays typically have been dominated by picoplankton $(0.2$ to $2.0 \mu \mathrm{m})$ and nanoplankton (2 to $20 \mu \mathrm{m}$ ) species (Cosper et al. 1989, Kim 1993, Lonsdale et al. 1996). The Peconic Bays also have been affected sporadically since 1985 by harmful 'brown tides' 
caused by a picoplanktonic pelagophyte, Aureococcus anophagefferens (Cosper et al. 1987, Bricelj \& Lonsdale 1997). Eutrophic WNB has repeatedly experienced high abundances of $A$. anophagefferens, typically in June or July. In contrast, the appearance of brown tides in $\mathrm{CH}$ has occurred only occasionally during the past $15 \mathrm{yr}$ when $A$. anophagefferens cells have reached bloom abundances throughout the entire Peconic Estuary System (SCDHS 1988-1989, Nuzzi \& Waters 1989, Nuzzi 1995).

The dominance of the phytoplankton community by small algae in Long Island bays implies an important role for microbial consumers as conduits for carbon, energy and nutrient flow in these estuaries. The size range of much of the algal community in $\mathrm{WNB}$ and $\mathrm{CH}$ is below the optimal range for particle capture by mesozooplankton (Nival \& Nival 1976, Bartram 1980). Accordingly, studies in the Peconic Estuary System during 1988-89 observed that grazers $>64 \mu \mathrm{m}$ in size did not contribute substantially to phytoplankton mortality during times when small algae comprised high percentages of the phytoplankton biomass (Kim 1993). Lonsdale et al. (1996) further showed that copepods depended on ciliate prey when picoplanktonic algae dominated the phytoplankton community in WNB. These observations support the supposition that phagotrophic protistan assemblages play a major role in the removal of phytoplankton production in Long Island bays.

Bacteria also make up a significant component of total picoplanktonic biomass in most coastal plankton communities (Ducklow 1983, Cole et al. 1988, Ducklow \& Carlson 1992). Long Island estuaries are no exception to this generality. High abundances of bacteria have been reported for a number of localities within the Peconic Estuary System and other Long Island estuaries (Caron et al. 1989). This finding implies a significant contribution of the microbial loop to energy

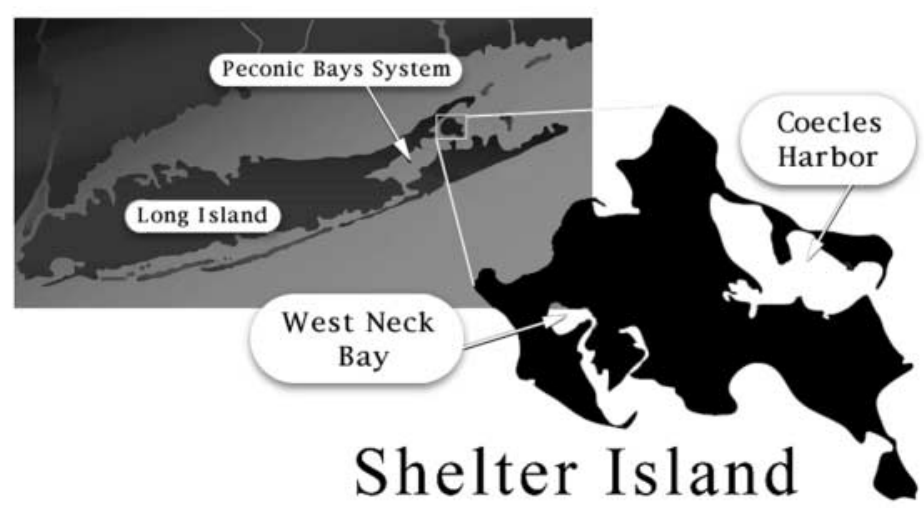

Fig. 1. Study site: Peconic Bays System, Long Island, NY. Water samples were collected at the northeastern shore of West Neck Bay and the western shore of Coecles Harbor. All incubations were performed at the study site in Coecles Harbor flow in these environments. This aspect of the planktonic food web of Long Island estuaries, however, has not been studied previously.

We investigated the role of protistan grazers in determining the fate of production in the Peconic Estuary System. Bacterivory and phytoplankton mortality (herbivory) were measured throughout the summer of 1998 in WNB and CH. Herbivory was determined using the dilution method. Bacterivory was estimated from the rate of disappearance of fluorescently labeled bacteria (FLB) during $24 \mathrm{~h}$ incubations. Our results indicate that major proportions of bacterial and primary production are channeled through the nano- and microzooplankton in these 2 bays.

\section{MATERIALS AND METHODS}

Field sites and sampling. WNB and $\mathrm{CH}$ are part of the Peconic Estuary System located on Shelter Island between the upper and lower forks of eastern Long Island, NY (Fig. 1). WNB is situated on the southwest side of Shelter Island, enclosed by an extension of land that restricts flow into and out of the bay. $\mathrm{CH}$ opens into the ocean side of the Peconic system on the eastern side of Shelter Island. $\mathrm{CH}$ has somewhat more exchange with the surrounding estuarine system than $\mathrm{WNB}$, but $\mathrm{CH}$ is also a larger body of water. These 2 estuaries were chosen because they represent different levels of eutrophication and different historical patterns in the occurrence of Aureococcus anophagefferens. Both were also close to our field laboratory.

Water samples were collected throughout the summer of 1998 on 16 dates in WNB and 14 dates in $\mathrm{CH}$ (Tables 1 \& 2). Samples were hand-collected just below the water surface to $0.5 \mathrm{~m}$ using acid-washed, $30 \mathrm{l}$ polyethylene carboys. An open carboy was inverted and lowered into the water with the spigot end up and open to allow air to be pushed out of the carboy as it filled, minimizing bubbling and damage to delicate plankton. One carboy was filled to make diluent for both bacterivory and herbivory experiments. A second carboy was filled for preservation of microbial populations and for employment in the grazing experiments. Temperature and salinity were measured at each sampling.

Microbial population estimates. Samples for the enumeration of Aureococcus anophagefferens, nanoplankton and bacteria were preserved immediately with $1 \%$ glutaraldehyde (final concentration) and stored at $4{ }^{\circ} \mathrm{C}$ in the dark. A. anophagefferens cells were probed and counted using the immunofluorescent technique of Anderson et al. (1989) using 


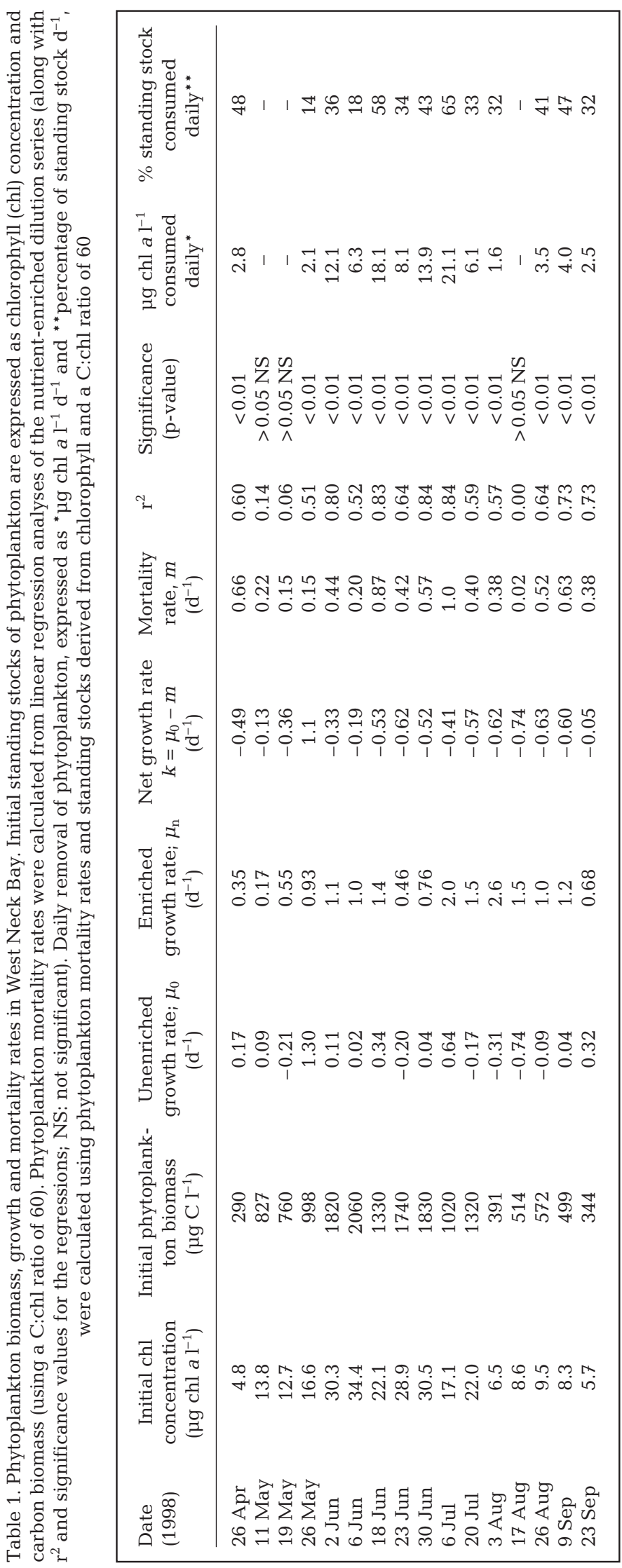

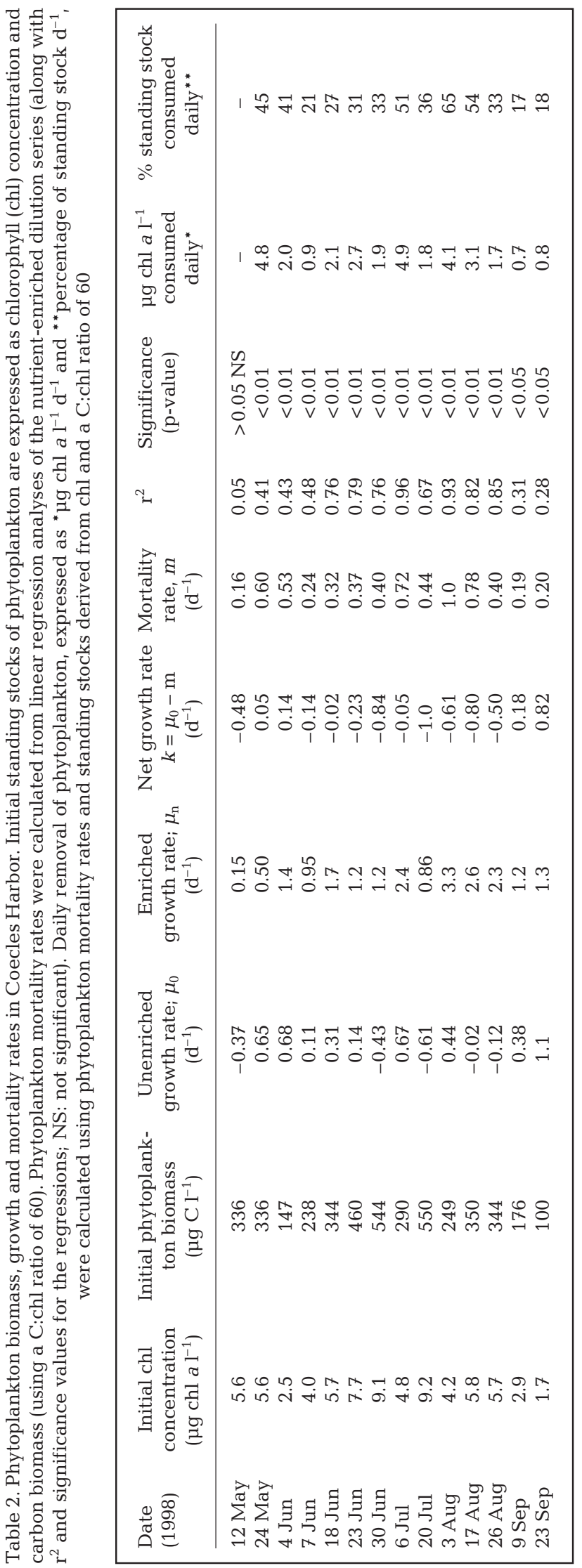


$0.8 \mu \mathrm{m}$ blackened polycarbonate filters. Nanoplankton were stained with 4',6-diamidino-2-phenylindole (DAPI) at 25 to $50 \mu \mathrm{g} \mathrm{ml}{ }^{-1}$ final stain concentration, which stains protists effectively, filtered onto $0.8 \mu \mathrm{m}$ blackened polycarbonate filters and counted using epiflourescence microscopy (Caron 1983, Sherr \& Sherr 1993a, Sherr et al. 1993). Nanoplankton could not be processed consistently within $24 \mathrm{~h}$ of collection and preservation because of the labor-intensive nature of the herbivory and bacterivory experiments. Therefore, heterotrophic and phototrophic nanoplankton were not distinguished in all samples, and counts are presented as total nanoplankton.

Samples for the determination of bacterial abundance were taken at the beginning of all grazing experiments in both WNB and $\mathrm{CH}$, as well as on many of the intervening days throughout the course of the summer in order to obtain better resolution of the short-term fluctuations in the abundance of this assemblage. Bacteria were stained with the nucleic acid dye Syto 13 (Molecular Probes ${ }^{\circledR}$, Eugene, OR, USA) and counted using a Becton Dickinson FACSCalibur flow cytometer (BD Bioscience, Mansfield, MA, USA; del Giorgio et al. 1996). Bacterial carbon biomass was estimated from bacterial abundance using a conversion factor of $20 \mathrm{fg} \mathrm{C} \mathrm{cell}^{-1}$ (Lee \& Fuhrman 1987).

Microplankton samples (20 to $200 \mu \mathrm{m}$ ) were preserved with Lugol's preservative (10\% final concentration) and stored in glass amber jars in the dark until processed (Stoecker et al. 1994). Samples were settled in counting chambers and enumerated using inverted light microscopy. Microplankton were grouped into major taxa as follows: diatoms, Prorocentrum sp., other dinoflagellates, non-loricate ciliates, tintinnids and other flagellates. Metazoa did not make up a significant fraction of microplankton abundances.

Chlorophyll analyses. Chlorophyll concentrations were determined fluorometrically (Strickland \& Parsons 1972) for all seawater samples, and on seawater passing through $5 \mu \mathrm{m}$ and $20 \mu \mathrm{m}$ Nitex $^{\circledR}$ screening (Sefar America, Kansas City, MO, USA). Subsamples were filtered onto Gelman GF/F glass fiber filters (Gelman Science, Ann Arbor, MI, USA) in triplicate. Chlorophyll was extracted in $100 \%$ acetone at $-20^{\circ} \mathrm{C}$ overnight in the dark and measured using a Turner Designs fluorometer Model TD-700 (Turner Designs, Sunnyvale, CA, USA).

Chlorophyll concentrations were converted to phytoplankton carbon using a carbon to chlorophyll (C:chl) ratio of 60 . This ratio was empirically determined on 2 dates in WNB during blooms of the dinoflagellate Prorocentrum sp. or the pelagophyte Aureococcus anophagefferens. The C:chl ratio during the dinoflagellate bloom (11 May) was determined from the chlorophyll concentration and from phytoplankton bio- volume converted to carbon using a conversion factor of $140 \mathrm{fg} \mathrm{C} \mathrm{mm}^{-3}$ (Lessard 1991). The C:chl ratio also was determined during the bloom of $A$. anophagefferens (30 June) by assuming that this alga dominated the chlorophyll biomass at the time, using a conversion factor of approximately $2.1 \mathrm{pg} \mathrm{C}$ cell $^{-1}$ to estimate phytoplankton carbon biomass (Milligan \& Cosper 1997). C:chl ratios on both dates were $\sim 60$. A ratio of 60 was applied to all samples taken during the study.

Phytoplankton growth and mortality rates. Phytoplankton growth rates and rates of phytoplankton mortality (microbial herbivory) were estimated using the refined dilution technique (Landry et al. 1995) but fluorescently labeled prey were not added. This method relies on dilution of herbivorous zooplankton with filtered seawater in the sample to create a gradient of phytoplankton mortality. Phytoplankton growth and mortality rates are determined from changes in apparent phytoplankton growth rate along the dilution gradient. All experimental containers, silicone transfer tubing, and filters were soaked in $10 \% \mathrm{HCl}$ and rinsed in Milli-Q water and/or filtered seawater prior to use. Filtrate was prepared by direct gravity flow of seawater through a $0.2 \mu \mathrm{m}$ Gelman cartridge filter previously soaked in $10 \% \mathrm{HCl}$ to remove dissolved organics. All work was performed with minimal bubbling. The dilution series consisted of $1200 \mathrm{ml}$ clear polycarbonate bottles with 20,40,60, 80 and $100 \%$ unfiltered seawater, each in triplicate.

A complete series of bottles were enriched with inorganic nutrients and trace metals (73.5 $\mu \mathrm{M} \mathrm{NaNO}_{3}$ $3.02 \mu \mathrm{M} \mathrm{NaH}{ }_{2} \mathrm{PO}_{4} \cdot \mathrm{H}_{2} \mathrm{O} ; 1 \mathrm{ml}$ of $\mathrm{f} / 2$ trace metals stock solution, Guillard 1975). An additional triplicate set of bottles with unfiltered seawater and without enrichment, and a control diluent bottle were incubated along with the enriched dilution series. Chlorophyll concentrations in the diluent control bottles were near the limit of analytical detection and never showed measurable increases during any of the experiments. Incubations for both WNB experiments and $\mathrm{CH}$ experiments were conducted for $24 \mathrm{~h}$ in $\mathrm{CH}$. Bottles were strung on a line at a depth of approximately $30 \mathrm{~cm}$ below the water surface. This incubation depth corresponded to $\sim 1 / 5(\mathrm{CH})$ and 1/3 (WNB) the depth of the entire water column at the sampling locations.

Replicate subsamples for chlorophyll analysis were taken at the end of the incubation from all experimental bottles. Subsamples were processed as described above (see 'Chlorophyll analyses'). Apparent net growth rates of the phytoplankton in each bottle were calculated from changes in chlorophyll a (chl a) concentration over the length of the experiment as $\mathrm{r}=$ $1 / t \times \ln \left(\mathrm{P}_{t} / P_{0}\right)$, where $t$ is time, $P_{0}$ is initial phytoplankton concentration and $P_{t}$ is final phytoplankton concentration. Growth rates of the phytoplankton assem- 
blages in the nutrient-enriched bottles $\left(\mu_{\mathrm{n}}\right)$ were determined from the $y$-intercepts of the regressions of apparent growth rate in the bottles versus dilution. Phytoplankton mortality rates $(m)$ were calculated from the slopes of the regressions. Phytoplankton growth rates in the unenriched bottles $\left(\mu_{0}\right)$ were obtained from net (apparent) growth rates of the phytoplankton in the unenriched, undiluted treatment (k) and the mortality rates $\left(\mu_{0}=k+m\right)$. This terminology is consistent with that of Landry et al. (1995).

Microbial bacterivory. Bacterial grazing rates were obtained by measuring the disappearance of FLB in unfiltered seawater samples during $24 \mathrm{~h}$ incubations (Marrasé et al. 1992, Salat \& Marrasé 1994). FLB were prepared from heat-killed and stained Halomonas halodurans (Sherr et al. 1987, Sherr \& Sherr 1993b). The bacterium is rod-shaped, approximately $0.4 \times$ $0.8 \mu \mathrm{m}$ when grown to starvation conditions. Seawater subsamples from the 301 carboys were dispensed into three $1200 \mathrm{ml}$ polycarbonate bottles and FLB were added at concentrations that were 10 to $30 \%$ of the abundance of natural bacteria $\left(5 \times 10^{5}\right.$ to $2 \times 10^{6} \mathrm{FLB}$ $\mathrm{ml}^{-1}$ ). For each experiment, FLB were also added to 3 control bottles $(0.2 \mu \mathrm{m}$ filtered seawater $)$ to monitor non-grazing related losses of FLB (e.g., adherence to the container walls). Bottles were incubated at approximately $0.5 \mathrm{~m}$ in $\mathrm{CH}$ as described above for the dilution experiments. Samples were removed from each bottle at the beginning and end of the experiment, and frozen and stored in liquid nitrogen until analyzed. Abundances of FLB were determined on a Becton Dickinson FACScan flow cytometer (BD Bioscience).

Grazing rates on bacteria were estimated from the rates of loss of FLB during the $24 \mathrm{~h}$ incubations, assuming an exponential decrease during the incubation period and assuming no significant changes in the abundances of total bacteria during the incubation. Grazing was calculated as $g=-1 / t \times \ln \left(F_{t} / F_{0}\right)$, where $t$ is time, $F_{0}$ is initial concentration of FLB and $F_{t}$ is final concentration of FLB. Twosample $t$-tests were performed to test significant differences between loss of FLB in whole seawater treatments and loss of FLB in control treatments. Changes in the abundance of FLB in control treatments were never significantly different from zero $(\mathrm{p}<0.01)$.

\section{RESULTS}

\section{Physical parameters}

The restricted flow into and out of WNB relative to $\mathrm{CH}$ was reflected in slightly higher temperatures and lower salinities in WNB (Fig. 2A,B). Temperature in both bays increased throughout May and June, peaked in July and August, and decreased in September. Overall average temperatures were 23.3 $\pm 3.5^{\circ} \mathrm{C}$ in WNB (range 13.5 to $27.3^{\circ} \mathrm{C}$ ) and $22.4 \pm 3.5^{\circ} \mathrm{C}$ in $\mathrm{CH}$ (range 13.5 to $26^{\circ} \mathrm{C}$ ). Salinity increased slightly from June to July in both bays. Mean salinities
Fig. 2. (A) Water temperature, (B) salinity, (C) total nanoplankton abundance and (D) Aureococcus anophagefferens abundance in West Neck Bay and Coecles Harbor during 1998. The vertical dashed line indicates the sampling date with the highest observed abundance of A. anophagefferens 
were $1.9 \%$ o higher in $\mathrm{CH}$ than WNB, averaging $27.5 \pm$ $0.87 \%$ in $\mathrm{CH}$ and $25.6 \pm 0.95 \%$ o in WNB during the study period.

\section{Phytoplankton and protozoa}

WNB had consistently higher protistan abundance or biomass than $\mathrm{CH}$ during this study. Chlorophyll values throughout the summer in WNB averaged

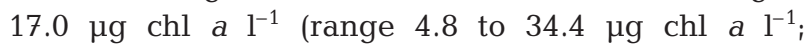
Table 1). Chlorophyll concentrations were significantly lower in $\mathrm{CH}$ than WNB, averaging $5.3 \mu \mathrm{g}$ chl a $\mathrm{l}^{-1}$ (range 1.7 to $9.2 \mu \mathrm{g} \mathrm{chl} \mathrm{a} \mathrm{l}^{-1}$; Table 2). Size-fractionated chlorophyll analyses indicated that the phytoplankton communities of both bays were composed primarily of pico- $(<2.0 \mu \mathrm{m})$ or nanoplanktonic (2 to 20 $\mu \mathrm{m})$ algae, except in late summer in $\mathrm{CH}$ when microplanktonic forms (i.e., $>20 \mu \mathrm{m}$ ) constituted a significant fraction of the total chlorophyll (Fig. 3). Most of the chlorophyll biomass in WNB occurred in the 5 to $20 \mu \mathrm{m}$ size class on 26 April and 11 May (Fig. 3A). This bay was dominated by flagellated species of

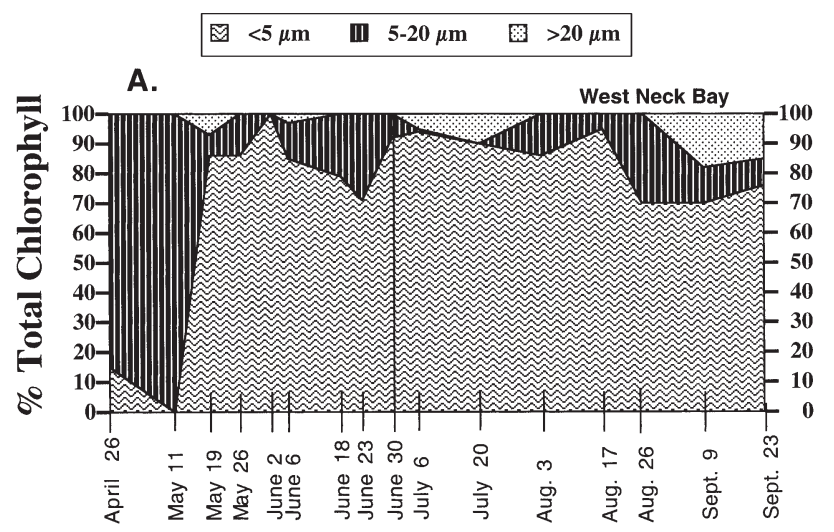

B.

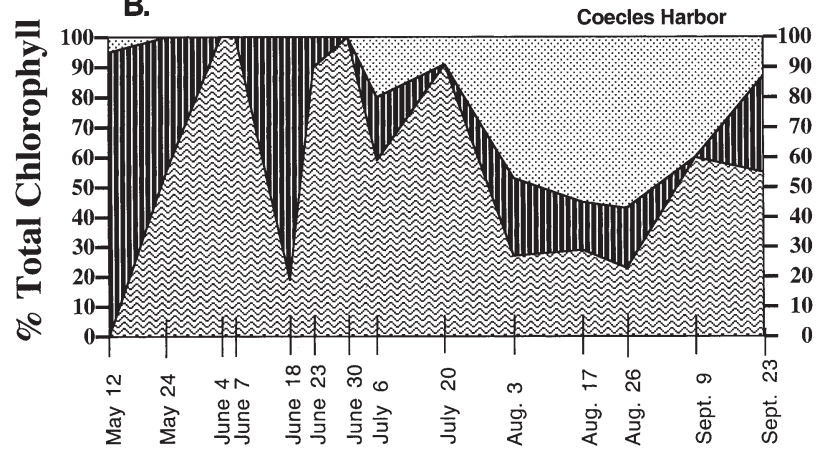

Fig. 3. Size-fractionated chlorophyll concentration (expressed as a percentage of the total chlorophyll) for (A) West Neck Bay and (B) Coecles Harbor. Total chlorophyll concentrations are given in Tables $1 \& 2$. The vertical dashed line in A indicates the sampling date with the highest observed abundance of Aureococcus anophagefferens phytoplankton cells $<5 \mu \mathrm{m}$ in size during the remainder of the study period (70 to $100 \%$ of total phytoplankton biomass). The size structure of the phytoplankton community of $\mathrm{CH}$ was more heterogeneous. Phytoplankton $<5,5$ to 20 and $>20 \mu \mathrm{m}$ in size each constituted more than $50 \%$ of the total phytoplankton biomass on several sampling dates (Fig. 3B).

Differences in phytoplankton (i.e., chlorophyll) biomass between the 2 bays were reflected in differences in the abundances of nano- and microplankton. Total (phototrophic and heterotrophic) nanoplankton abundances were generally 6 times higher in WNB than $\mathrm{CH}$, averaging $2.76 \times 10^{5}$ cells $\mathrm{ml}^{-1}$ in WNB (excluding Aureococcus anophagefferens) and $4.42 \times 10^{4}$ cells $\mathrm{ml}^{-1}$ in $\mathrm{CH}$ (Fig. 2C). Pico- and small nanoplanktonic phytoplankton (i.e., $<5 \mu \mathrm{m}$ ) were composed of a variety of taxa including cyanobacteria, A. anophagefferens and a variety of other small eukaryotes. A. anophagefferens contributed very significantly to abundance in this size fraction in WNB from late May to late July (Fig. 2D). The highest cell abundances of the brown tide alga observed were near-bloom concentrations of $8.80 \times 10^{5}$ cells ml ${ }^{-1}$ on 30 June. $\mathrm{CH}$ did not experience any significant buildup of $A$. anophagefferens. The latter cells were near the limit of detection throughout the study (less than a few hundred cells $\mathrm{ml}^{-1}$ ).

Cell concentrations of microplankton were $2.7 \times$ higher in WNB (WNB average of $4.44 \times 10^{4}$ cells $\mathrm{l}^{-1}$, $\mathrm{CH}$ average of $1.61 \times 10^{4}$ cells $\mathrm{l}^{-1}$; Fig. 4). Microplankton in both bays were dominated by cells $<40 \mu \mathrm{m}$ in size. A brief bloom $\left(1.64 \times 10^{6}\right.$ cells $\left.^{-1}\right)$ of Prorocentrum sp. was observed on 11 May in WNB. Prorocentrum sp. cell diameters were approximately $20 \mu \mathrm{m}$, and these cells were included with the microplankton in microscopical counts of these samples (Fig. 4A). However, the cells apparently passed through the $20 \mu \mathrm{m}$ Nitex $^{\circledR}$ screening and appeared largely in the 5 to $20 \mu \mathrm{m}$ chlorophyll size class on 11 May (Fig. 3A). Dinoflagellates (heterotrophic and phototrophic) other than Prorocentrum composed a large portion of the remainder of the microplankton community in the bays. In WNB, these dinoflagellates averaged $9.11 \times 10^{4}$ cells $\mathrm{l}^{-1}$, with peaks in May and August. Dinoflagellates averaged $4.99 \times 10^{4}$ cells $\mathrm{l}^{-1}$ in $\mathrm{CH}$ and exhibited peak concentrations in July and August.

Ciliate assemblages were dominated by aloricate ciliates in both bays on most sampling dates (Fig. 4B,D). Aloricate ciliates averaged $4.17 \times 10^{4}$ cells $\mathrm{l}^{-1}$ in WNB and $2.75 \times 10^{4}$ cells $\mathrm{l}^{-1}$ in $\mathrm{CH}$ throughout the study. Tintinnids outnumbered aloricate ciliates on only 2 dates, both of which coincided with high relative abundances of Prorocentrum sp. in WNB (11 May; Fig. 4B) and $\mathrm{CH}$ (6 July; Fig. 4D). 

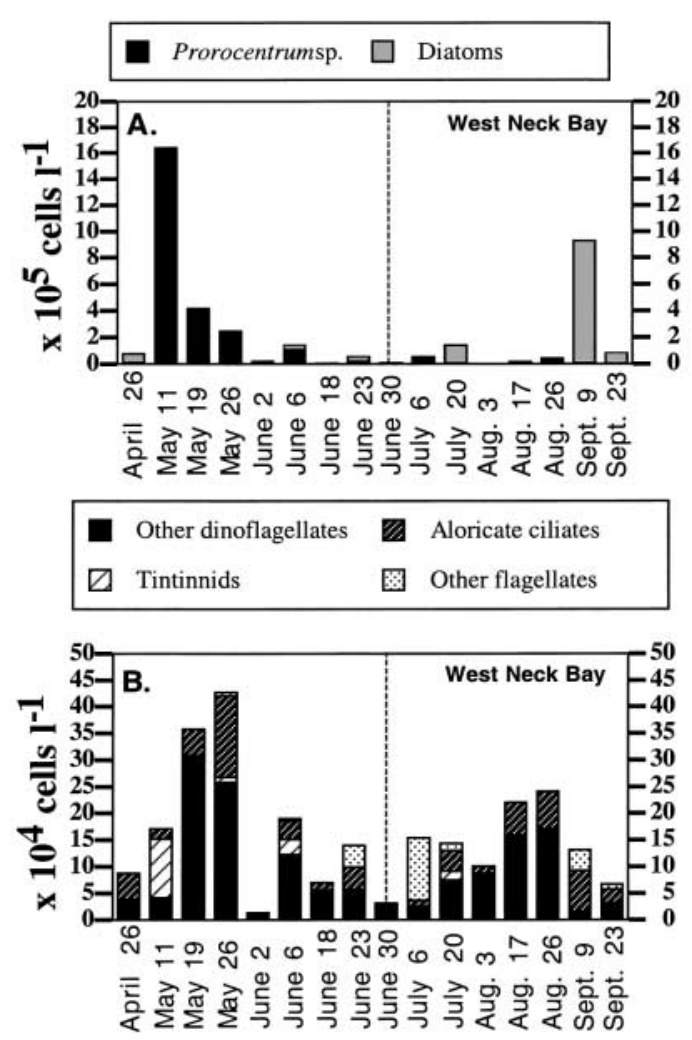
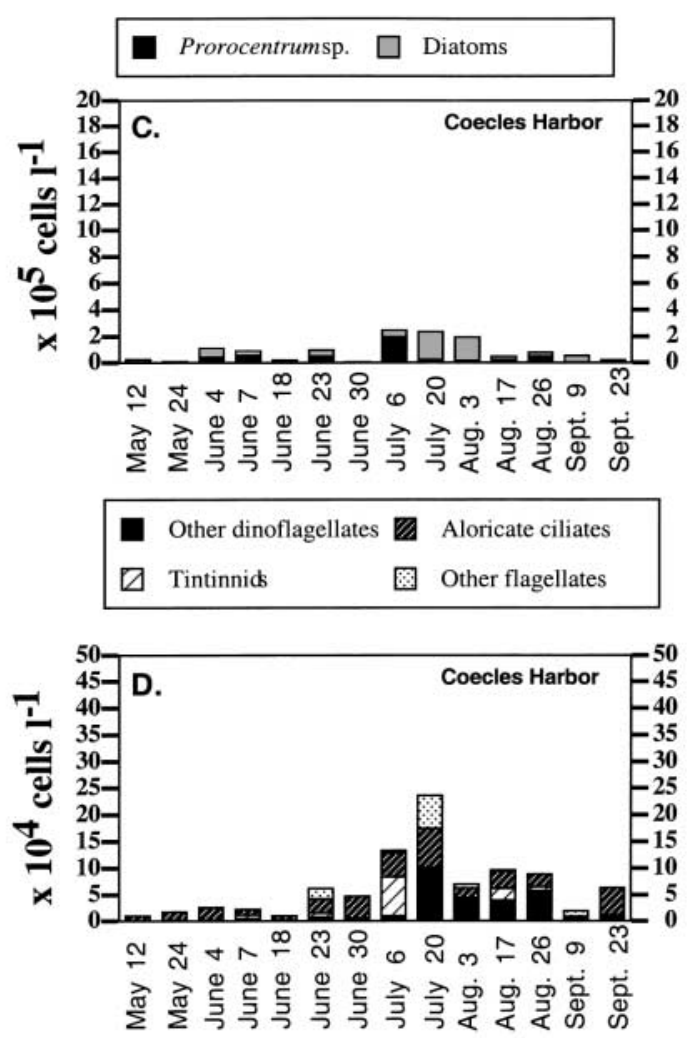

Fig. 4. Microplankton abundances in (A,B) West Neck Bay and (C,D) Coecles Harbor in 1998 grouped as (A,C) Prorocentrum sp. and diatoms, and $(B, D)$ other flagellates and ciliates. The vertical dashed line in $(A)$ and $(B)$ indicates the sampling date with the highest observed abundance of Aureococcus anophagefferens

\section{Phytoplankton growth and mortality}

Sixteen dilution experiments were performed in WNB from 26 April through 23 September, and 14 experiments were conducted in $\mathrm{CH}$ from 12 May through 23 September to examine phytoplankton growth and mortality rates (Tables $1 \& 2$ ). Thirteen of 16 experiments in WNB and 13 of 14 experiments in $\mathrm{CH}$ had regressions that were significantly different from 0 . Net phytoplankton growth rates $(k$, based on net changes in chlorophyll concentration in the unenriched, undiluted treatment) were very low for nearly all experiments and actually negative for most experiments (15 of 16 in WNB and 10 of 14 in $\mathrm{CH}$ ). Overall average net growth rates were $-0.35 \mathrm{~d}^{-1}$ for WNB and $-0.25 \mathrm{~d}^{-1}$ for $\mathrm{CH}$. In contrast, growth rates in the enriched bottles of the dilution series $\left(\mu_{\mathrm{n}}\right)$ were positive and, in most cases, rapid (overall averages of $1.2 \mathrm{~d}^{-1}$ in $\mathrm{WNB}$ and $1.6 \mathrm{~d}^{-1}$ in $\mathrm{CH}$ for regressions yielding significant slopes). The highest growth rates in both estuaries were obtained in the nutrientenriched treatments during the mid- to late summer. Gross phytoplankton growth rates in the absence of nutrient enrichment $\left(\mu_{0}=k+m\right)$ were variable during the study period (ranges -0.21 to $1.3 \mathrm{~d}^{-1}$ for WNB and -0.61 to $1.1 \mathrm{~d}^{-1}$ for $\mathrm{CH}$ for experiments with significant regressions). Overall averages for $\mu_{0}$ in these experiments were modest $\left(0.17 \mathrm{~d}^{-1}\right.$ for $\mathrm{WNB}$ and $0.25 \mathrm{~d}^{-1}$ for $\left.\mathrm{CH}\right)$.

Phytoplankton mortality rates determined by the dilution method were surprisingly similar in WNB and $\mathrm{CH}$ (Tables 1 \& 2). Average rates of mortality were $0.51 \pm 0.25 \mathrm{~d}^{-1}( \pm 1$ standard deviation $)$ in WNB for the significant regressions (range 0.15 to $1.0 \mathrm{~d}^{-1}$ ) and $0.48 \pm 0.25 \mathrm{~d}^{-1}$ in $\mathrm{CH}$ (range 0.19 to $1.0 \mathrm{~d}^{-1}$ ). These average rates were $0.41 \mathrm{~d}^{-1}(\mathrm{WNB})$ and $0.44 \mathrm{~d}^{-1}(\mathrm{CH})$ if non-significant regressions were included as mortality rates of 0 . Seasonal trends in mortality rate were not apparent, although the highest rates were observed during late June and early July in WNB and during August in $\mathrm{CH}$ (Figs 5 \& 6). Peaks in phytoplankton mortality rates were often offset from peaks in standing stocks of phytoplankton in both bays, implying predator-prey oscillations.

The average percentages of phytoplankton standing stocks removed per day were similar in both bays, owing to the similarity in mortality rates observed in the study. Removal rates averaged 38\% 


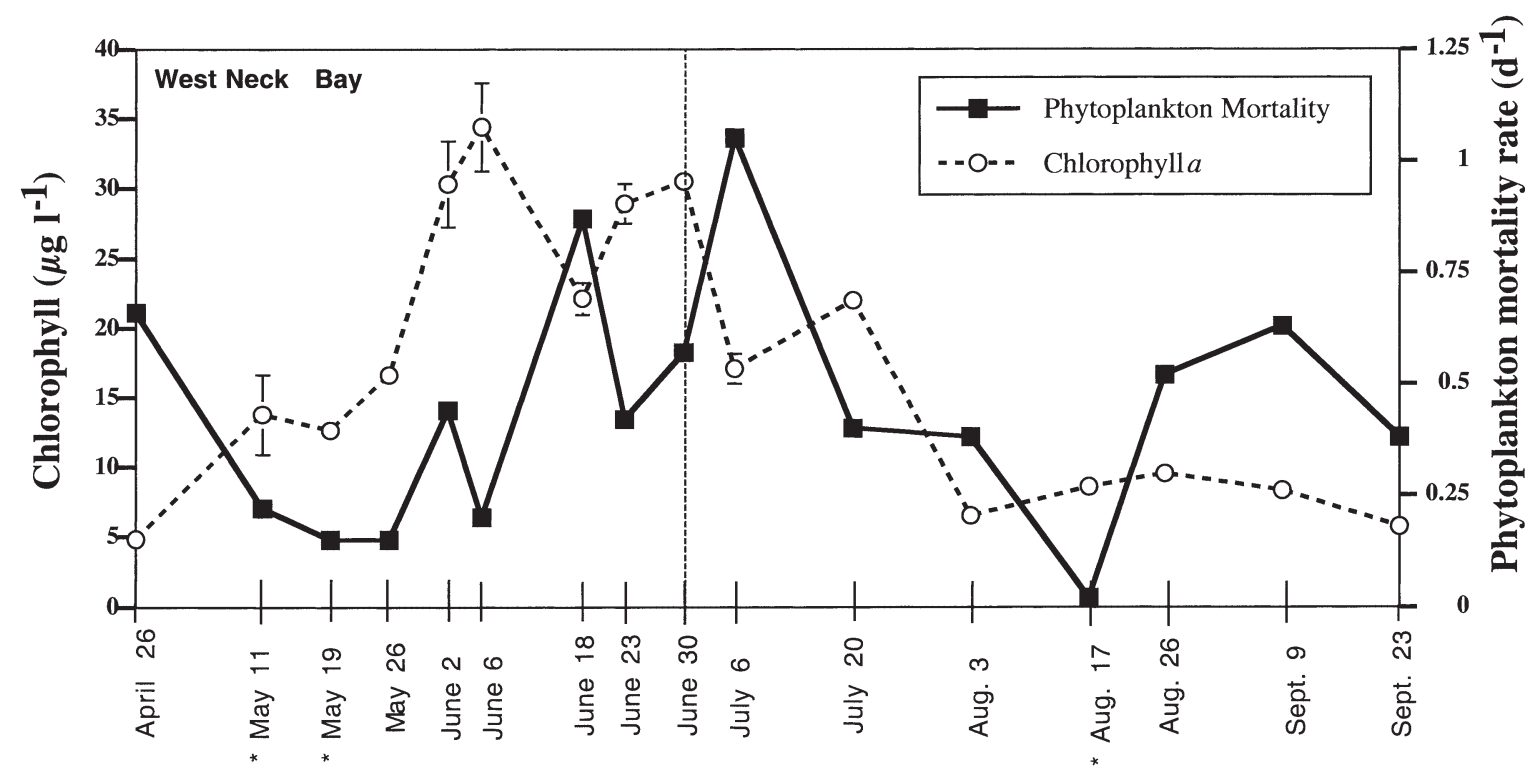

* Slope $(m=$ mortality $)$ not significant.

Fig. 5. Initial chlorophyll a concentrations and phytoplankton mortality rates determined from dilution experiments in West Neck Bay during 1998. Error bars for the chlorophyll concentrations are \pm 1 standard deviation of the mean. The vertical dashed line indicates the sampling date with the highest observed abundance of Aureococcus anophagefferens

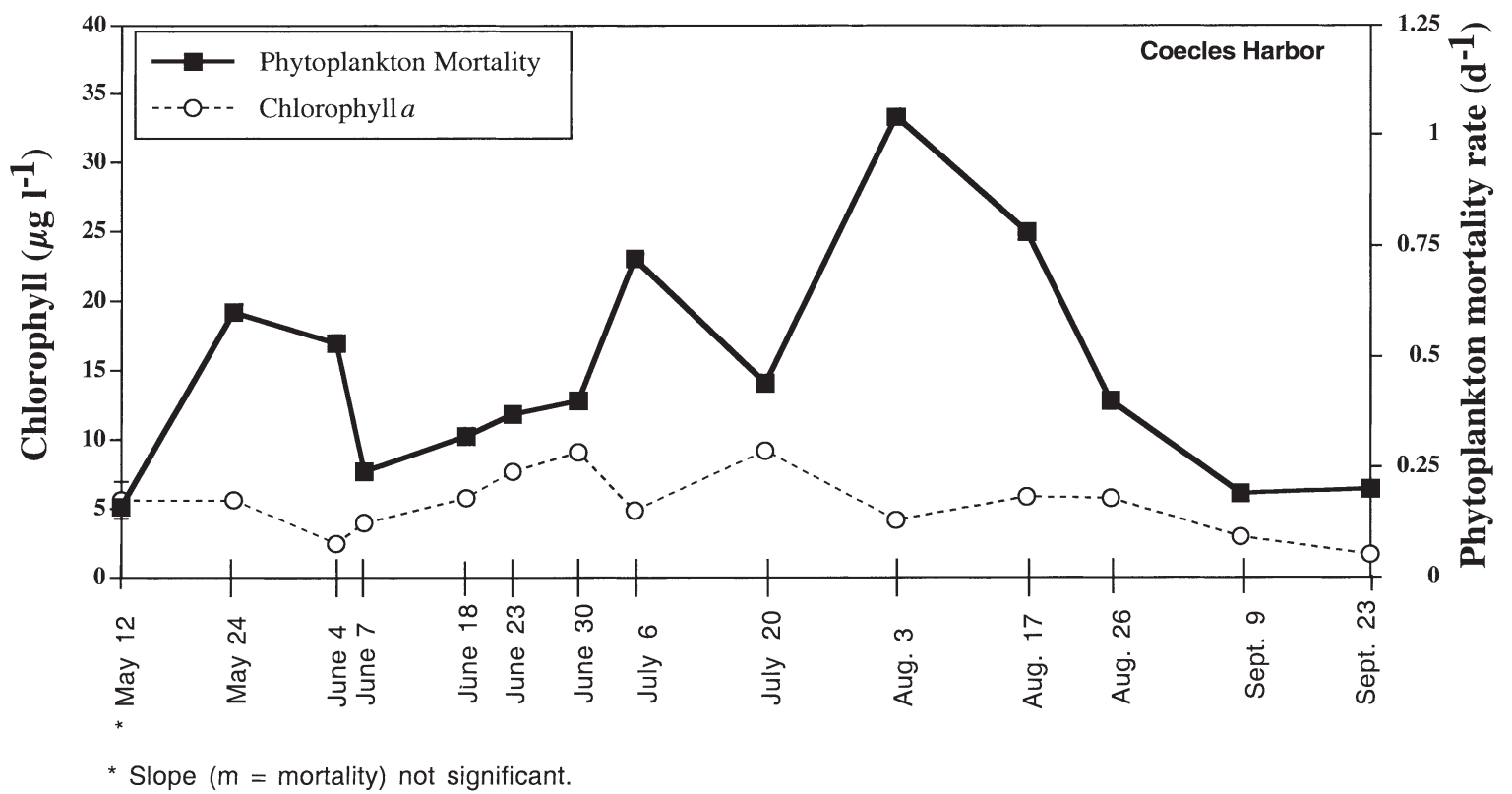

Fig. 6. Initial chlorophyll a concentrations and phytoplankton mortality rates determined from dilution experiments in Coecles Harbor during 1998. Error bars for the chlorophyll concentrations are \pm 1 standard deviation of the mean

in WNB (range 14 to $65 \%$ ) and $36 \%$ in $\mathrm{CH}$ (17 to $65 \%)$. However, absolute rates of biomass removal ( $\mu$ g $\mathrm{C}^{-1} \mathrm{~d}^{-1}$ ) were quite different for the 2 bays because of differences in the standing stocks of phytoplankton. The average absolute amounts of phytoplankton biomass consumed were estimated to be $471 \mu \mathrm{g} \mathrm{C} \mathrm{l}^{-1} \mathrm{~d}^{-1}\left(7.85 \mu \mathrm{g} \mathrm{chl} \mathrm{a} \mathrm{l}^{-1} \mathrm{~d}^{-1)}\right.$ in WNB and $146 \mu \mathrm{g} \mathrm{C} \mathrm{l}^{-1} \mathrm{~d}^{-1}\left(2.43 \mu \mathrm{g}\right.$ chl a $\mathrm{l}^{-1} \mathrm{~d}^{-1)}$ in $\mathrm{CH}$ using a $\mathrm{C}$ :chl ratio of 60 to convert chlorophyll to phytoplankton carbon (Tables $1 \& 2$ ). Maximal rates of phytoplankton biomass removal in WNB exceeded $1 \mathrm{mg} \mathrm{C}$ $\mathrm{l}^{-1} \mathrm{~d}^{-1}$ on 2 occasions. 
Table 3. Bacterial standing stocks and grazing rates in West Neck Bay. Standing stocks of bacteria are expressed as cell concentration and carbon biomass (assuming $20 \mathrm{fg} \mathrm{C} \mathrm{cell}^{-1}$ ). Bacterial grazing rates were calculated from the rate of loss of fluorescently labeled prey during $24 \mathrm{~h}$ incubations. Daily removal of bacteria, expressed as ${ }^{*}$ cells $\mathrm{ml}^{-1} \mathrm{~d}^{-1}$ and ${ }^{* *}$ percentage of standing stock $\mathrm{d}^{-1}$, were estimated from grazing rates and standing stocks

\begin{tabular}{|c|c|c|c|c|c|}
\hline $\begin{array}{l}\text { Date } \\
(1998)\end{array}$ & $\begin{array}{l}\text { Initial bacterial } \\
\text { cell concentration } \\
\left(\times 10^{6} \text { cells ml }{ }^{-1}\right)\end{array}$ & $\begin{array}{c}\text { Initial bacterial } \\
\text { biomass } \\
\left(\mu g \mathrm{C}^{-1}\right)\end{array}$ & $\begin{array}{l}\text { Grazing rate } \\
\qquad\left(\mathrm{d}^{-1}\right)\end{array}$ & $\begin{array}{l}\text { Bacterial cells ml }{ }^{-1} \\
\text { consumed daily* } \\
\left.\qquad \times 10^{6}\right)\end{array}$ & $\begin{array}{l}\% \text { standing stock } \\
\text { consumed daily }{ }^{* *}\end{array}$ \\
\hline 26 Apr & 4.38 & 88 & 0.32 & 1.20 & 27 \\
\hline 11 May & 3.41 & 68 & 0.73 & 1.77 & 52 \\
\hline 19 May & 5.16 & 103 & 0.47 & 1.95 & 38 \\
\hline 26 May & 8.34 & 167 & 0.54 & 3.49 & 42 \\
\hline 2 Jun & 13.3 & 266 & 0.16 & 1.93 & 14 \\
\hline 6 Jun & 12.8 & 256 & 0.21 & 2.41 & 19 \\
\hline 18 Jun & 12.8 & 256 & 0.67 & 6.23 & 49 \\
\hline 23 Jun & 15.4 & 308 & 0.75 & 8.15 & 53 \\
\hline 30 Jun & 17.0 & 340 & 0.57 & 7.43 & 44 \\
\hline $6 \mathrm{Jul}$ & 15.6 & 312 & 0.40 & 5.18 & 33 \\
\hline $20 \mathrm{Jul}$ & 10.4 & 208 & 0.68 & 5.12 & 49 \\
\hline 3 Aug & 19.8 & 396 & 1.2 & 14.0 & 71 \\
\hline 17 Aug & 11.6 & 232 & 0.49 & 4.50 & 39 \\
\hline 26 Aug & 13.1 & 262 & 0.42 & 4.53 & 35 \\
\hline 9 Sep & 14.2 & 284 & 0.87 & 8.27 & 58 \\
\hline 23 Sep & 7.81 & 156 & 0.53 & 3.20 & 41 \\
\hline
\end{tabular}

Table 4. Bacterial standing stocks and grazing rates in Coecles Harbor. Standing stocks of bacteria are expressed as cell concentration and carbon biomass (assuming $20 \mathrm{fg} \mathrm{C} \mathrm{cell}^{-1}$ ). Bacterial grazing rates were calculated from the rate of loss of fluorescently labeled prey during $24 \mathrm{~h}$ incubations. Daily removal of bacteria, expressed as ${ }^{*}$ cells $\mathrm{ml}^{-1} \mathrm{~d}^{-1}$ and ${ }^{* *}$ percentage of standing stock $\mathrm{d}^{-1}$, were estimated from grazing rates and standing stocks

\begin{tabular}{|c|c|c|c|c|c|}
\hline $\begin{array}{l}\text { Date } \\
(1998)\end{array}$ & $\begin{array}{l}\text { Initial bacterial } \\
\text { cell concentration } \\
\left(\times 10^{6} \text { cells ml }{ }^{-1}\right)\end{array}$ & 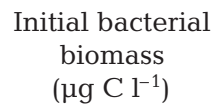 & $\begin{array}{l}\text { Grazing rate } \\
\qquad\left(\mathrm{d}^{-1}\right)\end{array}$ & $\begin{array}{l}\text { Bacterial cells ml }{ }^{-1} \\
\text { consumed daily }^{*} \\
\left.\qquad \times 10^{6}\right)\end{array}$ & $\begin{array}{l}\% \text { standing stock } \\
\text { consumed daily }{ }^{* *}\end{array}$ \\
\hline 12 May & 3.17 & 63 & 0.32 & 0.86 & 27 \\
\hline 24 May & 3.97 & 79 & 0.35 & 1.18 & 30 \\
\hline 4 Jun & 4.27 & 85 & 0.75 & 2.26 & 53 \\
\hline 7 Jun & 5.04 & 101 & 0.75 & 2.65 & 53 \\
\hline 18 Jun & 3.21 & 64 & 1.5 & 2.48 & 77 \\
\hline 23 Jun & 3.71 & 74 & 1.3 & 2.72 & 73 \\
\hline 30 Jun & 7.19 & 144 & 2.1 & 6.33 & 88 \\
\hline $6 \mathrm{Jul}$ & 9.11 & 182 & 0.43 & 3.17 & 35 \\
\hline $20 \mathrm{Jul}$ & 7.59 & 152 & 1.1 & 5.17 & 68 \\
\hline 3 Aug & 5.09 & 102 & 0.86 & 2.93 & 58 \\
\hline 17 Aug & 9.81 & 196 & 1.8 & 8.12 & 83 \\
\hline 26 Aug & 10.2 & 203 & 0.84 & 5.79 & 57 \\
\hline 9 Sep & 4.50 & 90 & 0.41 & 1.53 & 34 \\
\hline 23 Sep & 6.39 & 128 & 0.44 & 2.28 & 36 \\
\hline
\end{tabular}

\section{Bacteria and bacterivory}

Bacteria in WNB and $\mathrm{CH}$ were enumerated at the beginning of each experiment and on numerous other dates throughout the summer (Tables $3 \& 4$, Figs 7 \& 8). Bacterial abundances typically were more than twice as great in WNB than in $\mathrm{CH}$, averaging $1.31 \times 10^{7}$ cells $\mathrm{ml}^{-1}$ in WNB and $5.6 \times 10^{6} \mathrm{cell} \mathrm{ml}^{-1}$ in $\mathrm{CH}$. Fluctuations in abundance were similar for both ecosystems (a factor of approximately 5).
Bacterial grazing experiments were performed throughout the summer on the same days as phytoplankton mortality experiments. Rates of bacterivory averaged $0.57 \pm 0.07 \mathrm{~d}^{-1}$ in WNB and $0.93 \pm 0.31 \mathrm{~d}^{-1}$ in $\mathrm{CH}$ (Tables 3 \& 4). Rates of bacterivory in $\mathrm{CH}$ were significantly higher than in WNB ( $p<0.01, t$-test). Bacterial standing stocks were removed at average rates of $41 \% \mathrm{~d}^{-1}$ in WNB and $55 \% \mathrm{~d}^{-1}$ in $\mathrm{CH}$. However, the absolute amount of bacterial biomass consumed was greater in WNB than in $\mathrm{CH}$ because of the higher 


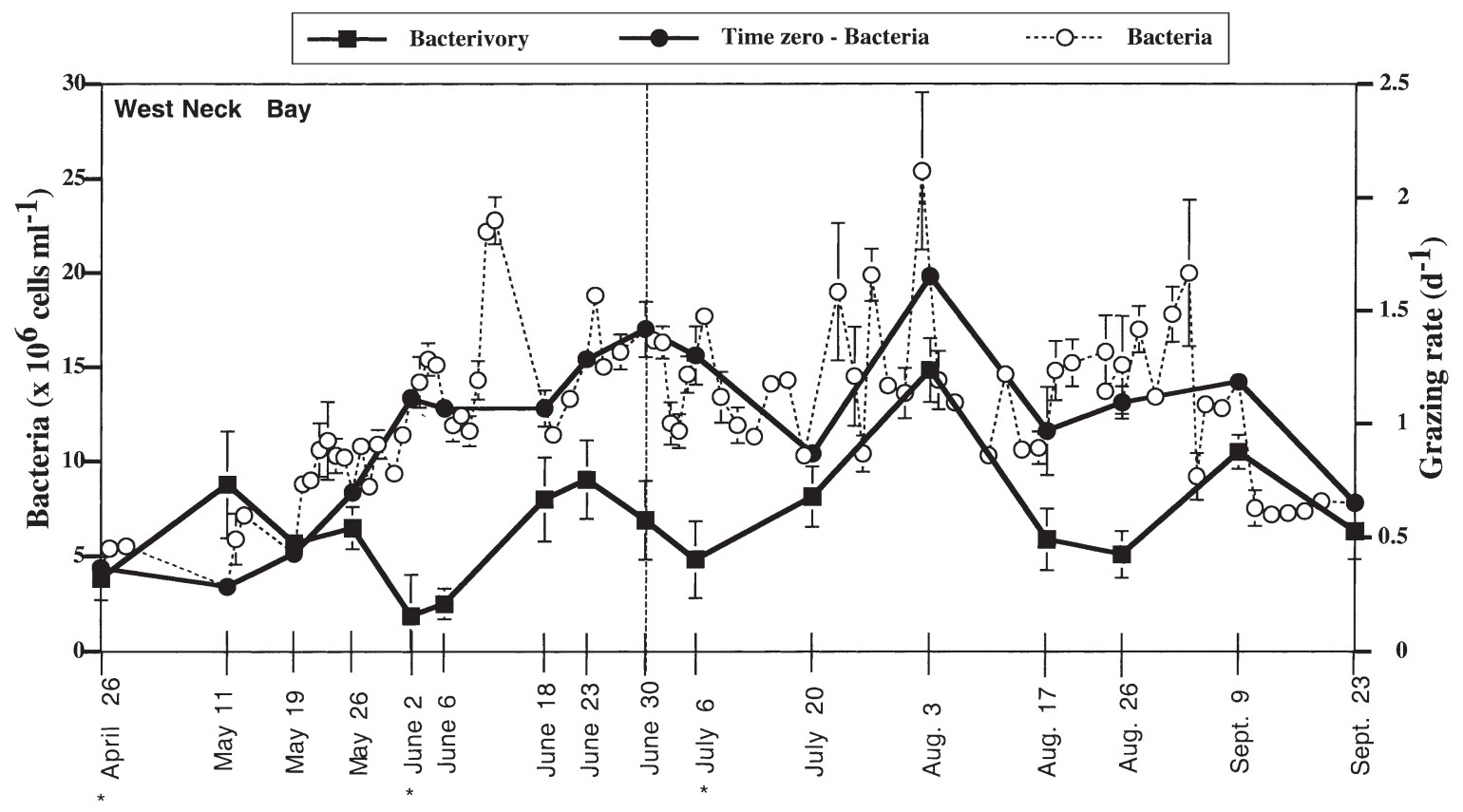

${ }^{*}$ Grazing not significantly greater than zero $(p>0.05)$.

Fig. 7. Bacterial abundances and rates of bacterivory in West Neck Bay during 1998. Bacterial abundances were determined at time 0 for grazing experiments (solid circles) and on multiple sampling dates throughout the summer (open circles). Rates of bacterivory (solid squares) are the means of triplicate bottles. All error bars are \pm 1 standard deviation of the mean. The vertical dashed line indicates the sampling date with the highest observed abundance of Aureococcus anophagefferens

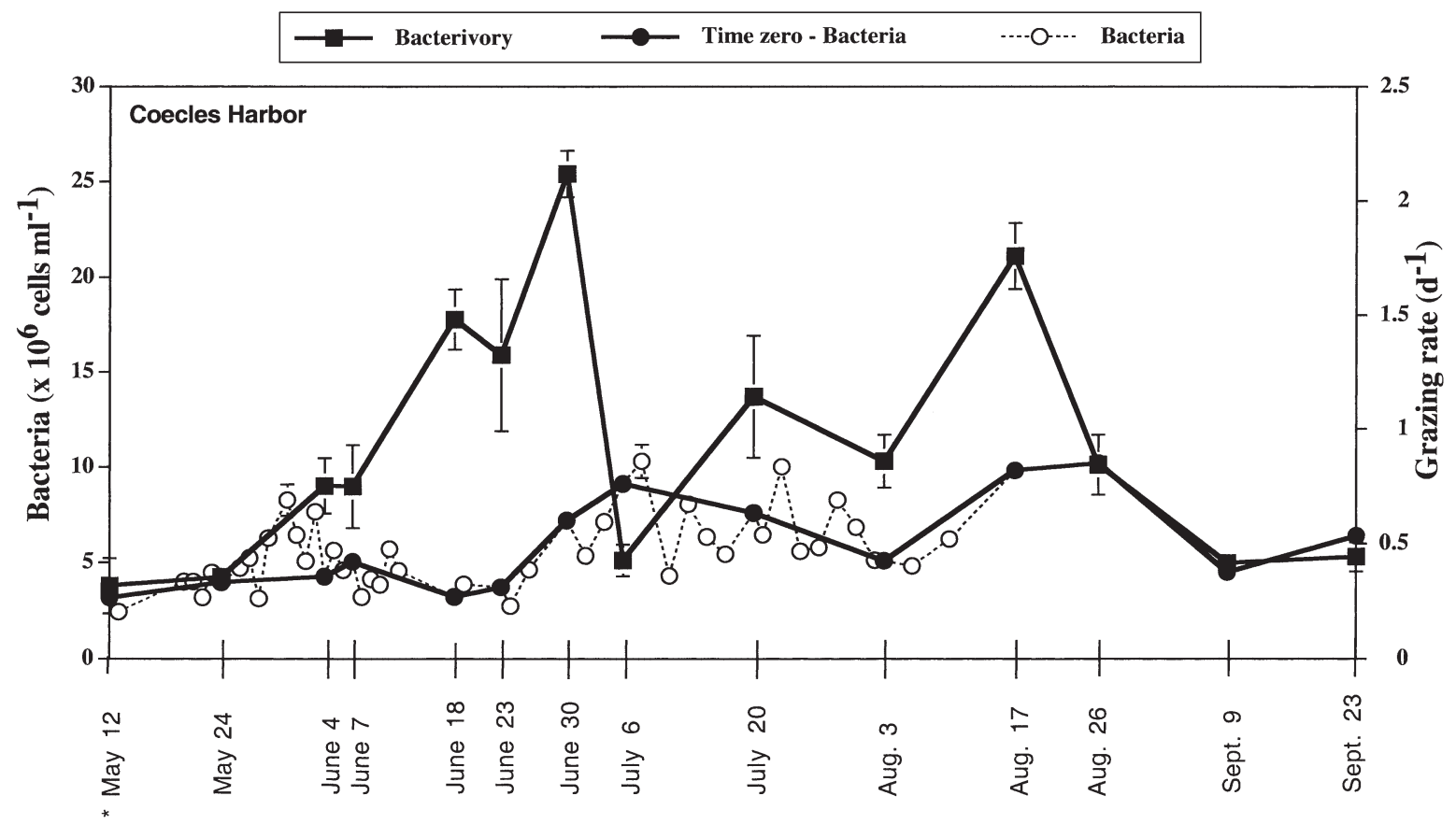

* Grazing not significantly greater than zero ( $p>0.05)$.

Fig. 8. Bacterial abundances and rates of bacterivory in Coecles Harbor during 1998. Bacterial abundances were determined at time 0 for grazing experiments (solid circles) and on multiple sampling dates throughout the summer (open circles). Rates of bacterivory (solid squares) are the means of triplicate bottles. All error bars are \pm 1 standard deviation of the mean 
abundances of bacteria present in WNB. Removal of bacterial biomass averaged $99 \mu \mathrm{C} \mathrm{C}^{-1} \mathrm{~d}^{-1}\left(4.96 \times 10^{6}\right.$ cells ml $\left.\mathrm{l}^{-1} \mathrm{~d}^{-1}\right)$ in WNB and $68 \mu \mathrm{g} \mathrm{C} \mathrm{l}^{-1} \mathrm{~d}^{-1}\left(3.39 \times 10^{6}\right.$ cells $\mathrm{ml}^{-1} \mathrm{~d}^{-1}$ ) in $\mathrm{CH}$ (Tables 3 \& 4). This comparison does not take into account differences in average bacterial size between the 2 environments. High rates of removal of bacterial biomass in WNB occurred throughout most of the mid-summer period, while peaks in the removal of bacterial biomass in $\mathrm{CH}$ corresponded to exceptionally high grazing rates on 30 June and 17 August (Figs 7 \& 8).

\section{DISCUSSION}

\section{Community structure}

Plankton abundances and biomasses in both WNB and $\mathrm{CH}$ were indicative of nutrient-rich, estuarine environments (Tables 1 to 4). However, hydrographic conditions, land runoff and groundwater intrusion presumably were different at the 2 study sites, and these differences were reflected in greater biological standing stocks in WNB than in $\mathrm{CH}$. Bacterial biomass and phytoplankton biomass estimates in WNB were comparable to those of other eutrophic estuaries on the east coast of the USA (Gallegos 1989, McManus \& Ederington-Cantrell 1992).

The chlorophyll concentrations observed in the present study were typical of seasonal ranges of chlorophyll observed previously in the Peconic Estuary System. Maximal chlorophyll concentrations of approx-

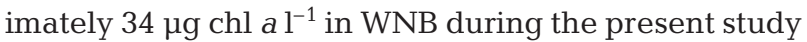
(Table 1) were similar to published reports for this estuary (Cosper et al. 1989, Lonsdale et al. 1996). A site in central Peconic Bay had a range of chlorophyll of 1 to $6.6 \mu \mathrm{g} \mathrm{chl} \mathrm{a} \mathrm{^{-1 }}$ (Bruno et al. 1980), similar to the range observed in $\mathrm{CH}$ in the present study (Table 2).

Phytoplankton assemblages were composed of small algae throughout much of the summer in both WNB and $\mathrm{CH}$ (Fig. 3). WNB was dominated by picoplanktonic eukaryotes, typically small chlorophytes or chrysophytes and Aureococcus anophagefferens, while $\mathrm{CH}$ was characterized by a range of phytoplankton including small chlorophytes, chrysophytes, diatoms and dinoflagellates. These results agree with previous studies that have investigated phytoplankton in the Peconic Bays. Studies in WNB have demonstrated the dominance of the phytoplankton community by algae $<5 \mu \mathrm{m}$ in size (Caron et al. 1989, Cosper et al. 1989, Nuzzi \& Waters 1989, Lonsdale et al. 1996). CH displayed more variability in the dominant size class of algae, but small nanoplankton and picoplankton contributed significantly to phytoplankton standing stocks in this bay (Fig. 3B).
Densities of bacteria in both bays also indicated eutrophic conditions. Bacterial abundances in WNB were near the upper limit of published reports for natural marine ecosystems, ranging from $3.4 \times 10^{6}$ to $2.5 \times$ $10^{7} \mathrm{cells} \mathrm{ml}^{-1}$ (Sanders et al. 1992, Simon et al. 1992). These values are comparable to the range previously reported for this embayment (Caron et al. 1989). Abundances were lower, but still substantial, in $\mathrm{CH}$, ranging from $3.2 \times 10^{6}$ to $1 \times 10^{7}$ cells ml $^{-1}$. Daily samplings of bacteria confirmed that abundances recorded on experimental days reflected the general trends observed throughout the summer (Figs 7 \& 8). However, occasional rapid changes in bacterial abundances illustrated that bacteria responded rapidly to environmental stimuli or removal processes (open circles and dotted lines in Figs 7 \& 8).

Phagotrophic protists are believed to be a major source of mortality for bacteria and small algae (Fenchel 1982, Campbell \& Carpenter 1986, McManus \& Fuhrman 1988, Sherr \& Sherr 1994). Heterotrophic (apochlorotic) protistan assemblages in this study were largely composed of nanoflagellates, and heterotrophic dinoflagellates and aloricate ciliates $<40 \mu \mathrm{m}$ in diameter. Larger heterotrophic protists $(>40 \mu \mathrm{m})$ and metazoa were minor components of the microzooplankton assemblages of both bays. These results imply that small phagotrophic protists probably were responsible for most of the grazing observed in this study.

Results from a 1988 study in WNB support the idea that small phagotrophic protists are major consumers of bacteria and algae in Long Island bays (Caron et al. 1989). That study demonstrated consumption of both fluorescently labeled algae (FLA) and FLB by nanoflagellates, dinoflagellates, ebridians, aloricate choreotrich cilates, tintinnids and scuticociliates. While community grazing was not evaluated, estimates of ingestion rates indicated that protistan taxa could constitute a significant source of mortality for these bacterial and algal populations.

\section{Phytoplankton growth and mortality}

Gross phytoplankton growth rates in the dilution bottles with nutrient additions $\left(\mu_{\mathrm{n}}\right.$ in Tables $\left.1 \& 2\right)$ were generally much greater than gross growth rates in the absence of nutrient additions ( $\mu_{0}$ in Tables $1 \& 2$ ). Differences in these rates were particularly striking for experiments performed in mid- to late summer. This finding implies that phytoplankton growth rates during many of the dilution experiments in this study could be increased by supplementing the assemblages with high concentrations of inorganic nutrients. Phytoplankton growth rates were increased 6 - to 7 -fold by 
the addition of nutrients (from 0.17 to $1.2 \mathrm{~d}^{-1}$ in WNB and from 0.25 to $1.6 \mathrm{~d}^{-1}$ in $\mathrm{CH}$ when averaged over all experiments yielding significant regressions).

Gross phytoplankton growth rates in the absence of nutrient enrichment $\left(\mu_{0}\right)$ were generally low relative to rates of mortality. The overall result was that most of the net phytoplankton growth rates observed in the unenriched dilution bottles were negative $(k$ in Tables 1 \& 2). This result would imply that phytoplankton mortality rates exceeded phytoplankton growth rates on most of the sampling dates. However, phytoplankton standing stock actually remained constant or increased between many of the experimental dates. We speculate that this contradiction is a consequence of photoadaptation of the phytoplankton assemblages at the high irradiances employed in the dilution experiments. We chose $0.3 \mathrm{~m}$ for the depth of incubation because it represented a substantial fraction of the total water column depth at our sampling sites in both environments ( 1.0 $\mathrm{m}$ in WNB and $\sim 1.5 \mathrm{~m}$ in $\mathrm{CH})$. We employed that depth in all incubations, and we performed all incubations in $\mathrm{CH}$. However, we suspect that high intensity at $0.3 \mathrm{~m}$ in $\mathrm{CH}$ was sufficient to result in reductions in pigment content per cell due to photoadaptation. A reduction in chlorophyll per cell during the incubation would result in an underestimation of the actual growth rates of the phytoplankton assemblage (McManus 1995). Our contention is supported by the results of several experiments in which phytoplankton growth rates in the absence of grazing mortality were negative $\left(\mu_{0}\right.$ in Tables $\left.1 \& 2\right)$. In the absence of grazing mortality, these rates should be $\geq 0$ assuming no reduction in per cell pigment content of the phytoplankton. Variable irradiance due to weather conditions among the days when experiments were performed would presumably result in variability in the degree of photoadaptation, and could help explain why only some of the experiments yielded negative values of $\mu_{0}$.

Significant rates of phytoplankton mortality were observed in 26 out of 30 dilution experiments in this study. Non-significant regressions may indicate that mortality rates are indistinguishable from zero or that one or more assumptions of the method have been violated. It should be noted that while photoadaptation of the phytoplankton community during incubation will result in underestimation of phytoplankton growth rates in dilution experiments, phytoplankton mortality rates should be unaffected as long as the adaptation is similar in all dilution bottles. This requirement was probably met in our experiments because significant self-shading in 11 bottles is highly unlikely. Ultraviolet light also should not have been a factor in these experiments (the incubation bottles absorb UV light), although adverse effects of high light intensity in the visible spectrum on protistan grazing activities cannot be ruled out in this study. Either of these perturbations (self-shading or light effects on phagotrophic protists) would presumably act to reduce the apparent mortality rates, and only during the daylight portion of the experiments. Thus, the rates observed in this study should represent at least lower limit estimates of microbial mortality.

Microzooplankton removed 14 to $65 \%$ of the daily standing stock in experiments yielding significant regressions (Tables 1 \& 2). Generally, the highest grazing rates occurred following peaks in algal biomass. This relationship implies grazer response to changes in phytoplankton abundance. Three-point regressions of the dilution curves in our study did not indicate saturation of grazing in any of the experiments (Gallegos 1989).

Our phytoplankton mortality results are indicative of phytoplankton community grazing impacts similar to those reported in other productive coastal areas. Table 5 presents a summary of published reports of phytoplankton mortality based on the dilution technique and standing stocks of primary producers (i.e., chlorophyll) from a variety of coastal ecosystems.

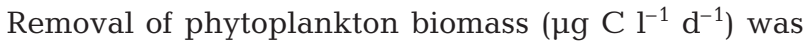
calculated for those studies using the same $\mathrm{C}$ :chl ratio (60) as that applied in the present study. Based on these calculations, reported rates of phytoplankton mortality in other coastal environments span a range of values that encompass the rates we observed. The highest rates were observed in the Estuary of Mundaka (Spain), Rhodes River (Chesapeake Bay, Maryland) and Atchafalaya River estuary (Louisiana) (averages for these studies were 3610, 10200 and $3270 \mu \mathrm{g} \mathrm{C} \mathrm{l}^{-1} \mathrm{~d}^{-1}$, respectively). These latter values are well in excess of the removal rates observed in the present study. We observed maximal rates of phytoplankton removal of approximately 1260 and $290 \mu \mathrm{g} \mathrm{Cl}^{-1} \mathrm{~d}^{-1}$ in $\mathrm{WNB}$ and $\mathrm{CH}$, respectively. Monthly averages of these removal rates were lower (49 to $815 \mu \mathrm{g} \mathrm{C}^{-1} \mathrm{~d}^{-1}$ in WNB and 47 to $217 \mu \mathrm{C} \mathrm{l}^{-1} \mathrm{~d}^{-1}$ in $\mathrm{CH}_{\text {; Table 5). }}$ Nevertheless, turnover rates for the phytoplankton assemblages (percentage standing stock of phytoplankton consumed per day) were similar in our study relative to those published reports (Table 5).

The choice of a C:chl ratio of 60 was based on calculations performed on 2 experimental dates in our study. Use of a different C:chl ratio would affect our estimates of carbon flow. C:chl ratios reported in the literature vary greatly $(\sim 20$ to $>100)$ for natural populations (Caron et al. 1995). The value employed in this study should provide a fairly conservative estimate of phytoplankton carbon consumption given that the phytoplankton assemblage showed evidence of nutrient limitation on most of the sampling dates (see above) and 
Table 5. Summary of dilution experiments from the 2 coastal bays examined in this study and from other marine environments. Initial chlorophyll (chl) concentrations and phytoplankton mortality rates for individual experiments are copied from reports, except as noted. Biomass consumed daily was calculated for each experiment as $\left(\mathrm{e}^{\mu_{0}}-\mathrm{e}^{k}\right) \times P_{0}$, where $\mu_{0}$ is gross algal growth coefficient, $k$ is net algal growth coefficient and $P_{0}$ is initial phytoplankton standing stock. Biomass consumed daily is reported as

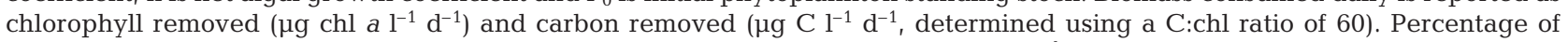
standing stock removed daily was calculated as $\left[\left(\mathrm{e}^{\mu_{0}}-\mathrm{e}^{k}\right) / \mathrm{e}^{\mu_{0}}\right] \times 100$

\begin{tabular}{|c|c|c|c|c|c|c|c|}
\hline Source & Study site & Date & $\begin{array}{l}\text { Initial chl conc. } \\
\left(\mu \mathrm{g} \mathrm{chl} \mathrm{al}^{-1}\right)\end{array}$ & $\begin{array}{l}\text { Phytoplankton } \\
\text { mortality rate } \\
\qquad\left(\mathrm{d}^{-1}\right)\end{array}$ & $\begin{array}{c}\text { Biomass } \\
\text { consumed daily } \\
\left(\mu \mathrm{g} \mathrm{chl} a \mathrm{l}^{-1} \mathrm{~d}^{-1}\right)\end{array}$ & 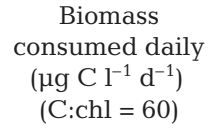 & $\begin{array}{l}\% \text { standing } \\
\text { stock con- } \\
\text { sumed daily }\end{array}$ \\
\hline $\begin{array}{l}\text { Present study } \\
\text { (monthly averages) }\end{array}$ & $\begin{array}{l}\text { Coecles Harbor } \\
\text { (Long Island) }\end{array}$ & $\begin{array}{l}\text { May } 98 \\
\text { Jun } 98 \\
\text { Jul } 98 \\
\text { Aug } 98 \\
\text { Sep } 98\end{array}$ & $\begin{array}{l}5.60 \\
5.80 \\
7.00 \\
5.00 \\
2.30\end{array}$ & $\begin{array}{l}0.38 \\
0.37 \\
0.58 \\
0.91 \\
0.20\end{array}$ & $\begin{array}{l}2.70 \\
1.92 \\
3.35 \\
3.60 \\
0.75\end{array}$ & $\begin{array}{r}163 \\
116 \\
199 \\
217 \\
47\end{array}$ & $\begin{array}{l}30 \\
31 \\
44 \\
60 \\
18\end{array}$ \\
\hline $\begin{array}{l}\text { Present study } \\
\text { (monthly averages) }\end{array}$ & $\begin{array}{l}\text { West Neck Bay } \\
\text { (Long Island) }\end{array}$ & $\begin{array}{l}\text { Apr } 98 \\
\text { May } 98 \\
\text { Jun } 98 \\
\text { Jul } 98 \\
\text { Aug } 98 \\
\text { Sep } 98\end{array}$ & $\begin{array}{r}4.80 \\
14.37 \\
29.24 \\
19.55 \\
8.20 \\
7.00\end{array}$ & $\begin{array}{l}0.66 \\
0.17 \\
0.50 \\
0.73 \\
0.31 \\
0.51\end{array}$ & $\begin{array}{r}2.80 \\
2.17 \\
11.70 \\
13.60 \\
1.73 \\
3.25\end{array}$ & $\begin{array}{l}166 \\
130 \\
701 \\
815 \\
103 \\
196\end{array}$ & $\begin{array}{l}48 \\
16 \\
38 \\
49 \\
25 \\
40\end{array}$ \\
\hline Burkill et al. (1987) & $\begin{array}{l}\text { Carmarthen Bay } \\
\text { Celtic Sea }\end{array}$ & $\begin{array}{l}\text { Oct } 84 \\
\text { Jul } 83 \\
\text { Jul } 83 \\
\text { Oct } 84\end{array}$ & $\begin{array}{l}4.69 \\
2.18 \\
0.72 \\
0.74\end{array}$ & $\begin{array}{l}0.36 \\
0.38 \\
0.55 \\
1.04\end{array}$ & $\begin{array}{l}2.01 \\
0.81 \\
0.42 \\
0.68\end{array}$ & $\begin{array}{r}121 \\
49 \\
25 \\
41\end{array}$ & $\begin{array}{l}30 \\
32 \\
42 \\
65\end{array}$ \\
\hline $\begin{array}{l}\text { Landry \& Hassett } \\
\text { (1982) }\end{array}$ & Washington coast & $\begin{array}{l}\text { Oct } 80 \\
\text { Oct } 80 \\
\text { Oct } 80\end{array}$ & $\begin{array}{l}3.54 \\
2.03 \\
6.77\end{array}$ & $\begin{array}{l}0.28 \\
0.07 \\
0.12\end{array}$ & $\begin{array}{l}1.61 \\
0.20 \\
1.41\end{array}$ & $\begin{array}{l}97 \\
12 \\
84\end{array}$ & $\begin{array}{r}24 \\
6 \\
12\end{array}$ \\
\hline Gifford (1988) & $\begin{array}{l}\text { Halifax Harbour } \\
\text { (Nova Scotia) }\end{array}$ & $\begin{array}{l}30 \text { Aug } 84 \\
13 \text { Nov } 84 \\
11 \text { Mar } 85 \\
15 \text { Apr } 85 \\
5 \text { Jun } 85\end{array}$ & $\begin{array}{l}1.90 \\
2.20 \\
0.30 \\
1.80 \\
1.80\end{array}$ & $\begin{array}{l}0.24 \\
0.02 \\
0.72 \\
0.24 \\
0.48\end{array}$ & $\begin{array}{l}0.83 \\
0.07 \\
0.32 \\
0.62 \\
3.68\end{array}$ & $\begin{array}{r}50 \\
4 \\
19 \\
37 \\
221\end{array}$ & $\begin{array}{r}21 \\
2 \\
51 \\
21 \\
38\end{array}$ \\
\hline $\begin{array}{l}\text { Murrell \& Hollibaugh } \\
\text { (1998) }\end{array}$ & $\begin{array}{l}\text { Tomales Bay (San } \\
\text { Fransisco Bay) }\end{array}$ & $\begin{array}{l}\text { Jul } 94 \\
\text { Jul } 94\end{array}$ & $\begin{array}{l}7.30 \\
5.30\end{array}$ & $\begin{array}{l}0.24 \\
1.14\end{array}$ & $\begin{array}{l}1.61 \\
5.54\end{array}$ & $\begin{array}{r}96 \\
333\end{array}$ & $\begin{array}{l}21 \\
68\end{array}$ \\
\hline $\begin{array}{l}\text { McManus \& } \\
\text { Ederington-Cantrell } \\
\text { (1992) } \\
\text { (summer months) }\end{array}$ & $\begin{array}{l}\text { Chesapeake Bay } \\
\text { (Upper Bay) } \\
\text { Chesapeake Bay } \\
\text { (Mid-Bay) }\end{array}$ & $\begin{array}{l}16 \text { May } 90 \\
14 \text { Aug } 90 \\
17 \text { May } 90 \\
15 \text { Aug } 90 \\
16 \text { Aug } 90\end{array}$ & $\begin{array}{rr}90 & 2.18 \\
90 & 6.76 \\
90 & 19.47 \\
90 & 7.23 \\
90 & 11.31\end{array}$ & $\begin{array}{l}0.76 \\
1.60 \\
0.43 \\
0.20 \\
0.25\end{array}$ & $\begin{array}{r}9.96 \\
37.92 \\
10.25 \\
1.77 \\
2.94\end{array}$ & $\begin{array}{r}598 \\
2275 \\
615 \\
106 \\
176\end{array}$ & $\begin{array}{l}53 \\
80 \\
35 \\
18 \\
22\end{array}$ \\
\hline $\begin{array}{l}\text { Ruiz et al. } \\
\text { (1998) } \\
\text { (mean values for } \\
3 \text { salinity ranges) }\end{array}$ & $\begin{array}{c}\text { Mundaka, Spain } \\
(<25 \%) \\
(25-31 \%) \\
(>31 \%)\end{array}$ & $\begin{array}{l}\text { Aug } 90 \\
\text { Aug } 90 \\
\text { Aug } 90\end{array}$ & $\begin{array}{r}62.00 \\
6.37 \\
4.83\end{array}$ & $\begin{array}{l}0.54 \\
0.80 \\
0.94\end{array}$ & $\begin{array}{r}128.13 \\
21.43 \\
31.06\end{array}$ & $\begin{array}{l}7688 \\
1286 \\
1864\end{array}$ & $\begin{array}{l}42 \\
55 \\
61\end{array}$ \\
\hline Gallegos (1989) & $\begin{array}{l}\text { Rhode River, MD } \\
\text { (Chesapeake Bay) }\end{array}$ & $\begin{array}{l}6 \text { Jul } 88 \\
9 \text { Aug } 88 \\
30 \text { Aug } 88 \\
4 \text { Oct } 88\end{array}$ & $\begin{array}{rr} & 34.80 \\
8 & 81.80 \\
38 & 138.40 \\
32.50\end{array}$ & $\begin{array}{l}2.01 \\
1.52 \\
0.42 \\
0.66\end{array}$ & $\begin{array}{r}300.59 \\
275.19 \\
76.71 \\
30.38\end{array}$ & $\begin{array}{r}18036 \\
16511 \\
4602 \\
1823\end{array}$ & $\begin{array}{l}87 \\
78 \\
34 \\
48\end{array}$ \\
\hline Dagg (1995) & $\begin{array}{c}\text { Atchafalaya River } \\
\text { Estuary }\end{array}$ & $\begin{array}{l}\text { Jan } 90 \\
\text { Apr } 90 \\
\text { Sep } 90 \\
\text { Sep } 90 \\
\text { Aug } 91 \\
\text { Aug } 91\end{array}$ & $\begin{array}{l}16.45 \\
14.31 \\
24.49 \\
21.44 \\
27.11 \\
17.31\end{array}$ & $\begin{array}{l}0.54 \\
0.32 \\
2.11 \\
0.84 \\
1.38 \\
1.08\end{array}$ & $\begin{array}{r}10.87 \\
6.44 \\
180.81 \\
29.32 \\
73.45 \\
26.15\end{array}$ & $\begin{array}{r}652 \\
386 \\
10849 \\
1759 \\
4407 \\
1569\end{array}$ & $\begin{array}{l}42 \\
28 \\
87 \\
51 \\
81 \\
71\end{array}$ \\
\hline
\end{tabular}

given that C:chl ratio typically increases with increasing nutrient limitation.

Collectively, these studies indicate that nano- and microzooplankton control the fate of much of the primary production in eutrophic estuarine ecosystems. This result is presumably a consequence of the dominance of these phytoplankton communities by pico- or nanophytoplankton during much of the growing season. However, microbial grazing during periods when microplanktonic phytoplankton (i.e., > $20 \mu \mathrm{m}$ ) dominated the phytoplankton assemblages was also evident (Fig. 3B). Presumably, phagotrophic dinoflagellates, tintinnids and non-loricate ciliates accounted for this activity. High estimates of microbial grazing in 
these ecosystems implies that phagotrophic protists constitute an important trophic link for carbon transfer in the pelagic food webs of these environments.

During this study, the appearance of Aureococcus anophagefferens in WNB presented the opportunity to investigate the impact of this alga on phytoplankton mortality rates. A. anophagefferens has been reported to produce a dopamine-like compound that inhibits neurotransmission, which reduces ciliary feeding action in bivalves (Gainey \& Shumay 1991). Previous studies have suggested that $A$. anophagefferens may have similar effects on microzooplankton, inhibiting growth and grazing by phagotrophic protists (Lonsdale et al. 1996, Mehran 1996). Nonetheless, multiple regression analyses between $A$. anophagefferens and grazing mortality in our study did not reveal any obvious impact of this alga on grazing activity. The phytoplankton mortality rate during peak $A$. anophagefferens population abundance on 30 June in WNB was $0.57 \mathrm{~d}^{-1}$. Moreover, we have successfully cultured several species of protozoa that are capable of consuming and growing on $A$. anophagefferens in the laboratory (Caron \& Bossoinneault-Cellineri unpubl. data). We speculate that the contradictory nature of these past and present findings may relate to the absolute (or relative) abundance of $A$. anophagefferens in the water, aspects of the physiological state of $A$. anophagefferens or the presence of microbial consumers that can feed on the alga.

\section{Bacterivory}

Bacterial mortality due to protistan grazing was measured by monitoring the rate of disappearance of FLB. Advantages of this method include the acquisition of absolute estimates of bacterial grazing, minimal manipulation of samples and fairly easy evaluation of samples using flow cytometry. Several caveats also exist regarding the applicability and accuracy of this method. Feeding selectivity by grazers, resulting in over- or underestimation of bacterivore grazing activity, can occur. Heat-killing and labeling cells may affect acceptability of prey to some protists based on chemical cues (Landry et al. 1991), although evidence indicates that many phagotrophic protists select and digest fluorescently labeled prey similarly to natural prey (Sherr et al. 1988, Dolan \& Simek 1997). Grazing may be overestimated if bacterivores prefer larger cells (González et al. 1990). For this reason we prepared FLB from late stationary phase cultures to generate cells that more closely resembled the size of natural bacteria from these estuarine ecosystems.

Bacterivore populations exerted strong grazing pressure on bacterioplankton in both WNB and CH. Graz- ing rates were higher in $\mathrm{CH}$ (overall average of $0.93 \mathrm{~d}^{-1}$ ) than in WNB (overall average of $0.57 \mathrm{~d}^{-1}$ ), indicating that turnover rates of the bacteria as a consequence of bacterivory were more rapid in the less eutrophic environment. We speculate that the faster turnover rate of the bacterial assemblage in $\mathrm{CH}$ may be related to assessibility of these cells (WNB had a much higher load of particulate material that might facilitate bacterial attachment or provide refuge from grazing). Alternatively, our rates do not include losses due to viral lysis, and this process may be more important in WNB because of higher bacterial abundances in that bay.

Bacterial abundances showed low amplitude, shortterm (one to a few days) fluctuations but were relatively stable over the course of the summer in both bays. This observation indicates that growth and grazing were in approximate balance throughout the course of the summer. A 1:1 correspondence between bacterial production and grazing in most pelagic ecosystems has been noted (Sanders et al. 1992). This situation in these 2 Long Island bays implies that growth rates of the bacterial assemblages must have been considerable in order to compensate for losses due to protistan mortality.

The rapid rates of bacterial removal observed in WNB and $\mathrm{CH}$ in this study, combined with the large standing stocks of bacteria in these ecosystems, resulted in considerable amounts of carbon flow through this aspect of the microbial community (Tables 3 \& 4). Overall averages for daily carbon flux through bacterivores in the present study were 99 and $68 \mu \mathrm{g} \mathrm{C}^{-1} \mathrm{~d}^{-1}$ in WNB and $\mathrm{CH}$, respectively. Removal rates of bacterial standing stocks in $\mathrm{WNB}$ and $\mathrm{CH}$ were similar to or greater than most rates published for other marine ecosystems (Coffin \& Sharp 1987, Weisse 1989, Wikner et al. 1990, Wikner \& Hagström 1991, Marrasé et al. 1992, Reckermann \& Veldhuis 1997, Murrell \& Hollibaugh 1998, Caron et al. 1999, Weisse 1999). Standing stocks of bacteria were twice as high in WNB as in $\mathrm{CH}$. Nevertheless, differences between estimates of carbon flow via bacterivory in the 2 bays differed by a factor of only $\sim 1.4$ due to higher average mortality rates in $\mathrm{CH}$ (i.e., more rapid turnover of the bacterial assemblage).

It is important to note, however, that this comparison assumes a constant bacterial cell carbon content of $20 \mathrm{fg} \mathrm{C}$ for both ecosystems. While this number facilitates calculation of carbon from cell number, it is undoubtedly inappropriate to some degree for either environment. Cell volume was not determined in this study but microscopical examinations indicated that cell sizes of the bacteria in WNB were quite large at some times. Thus, 1.4 should be considered a minimal difference in carbon flow via bacterivory between the 2 environments. 

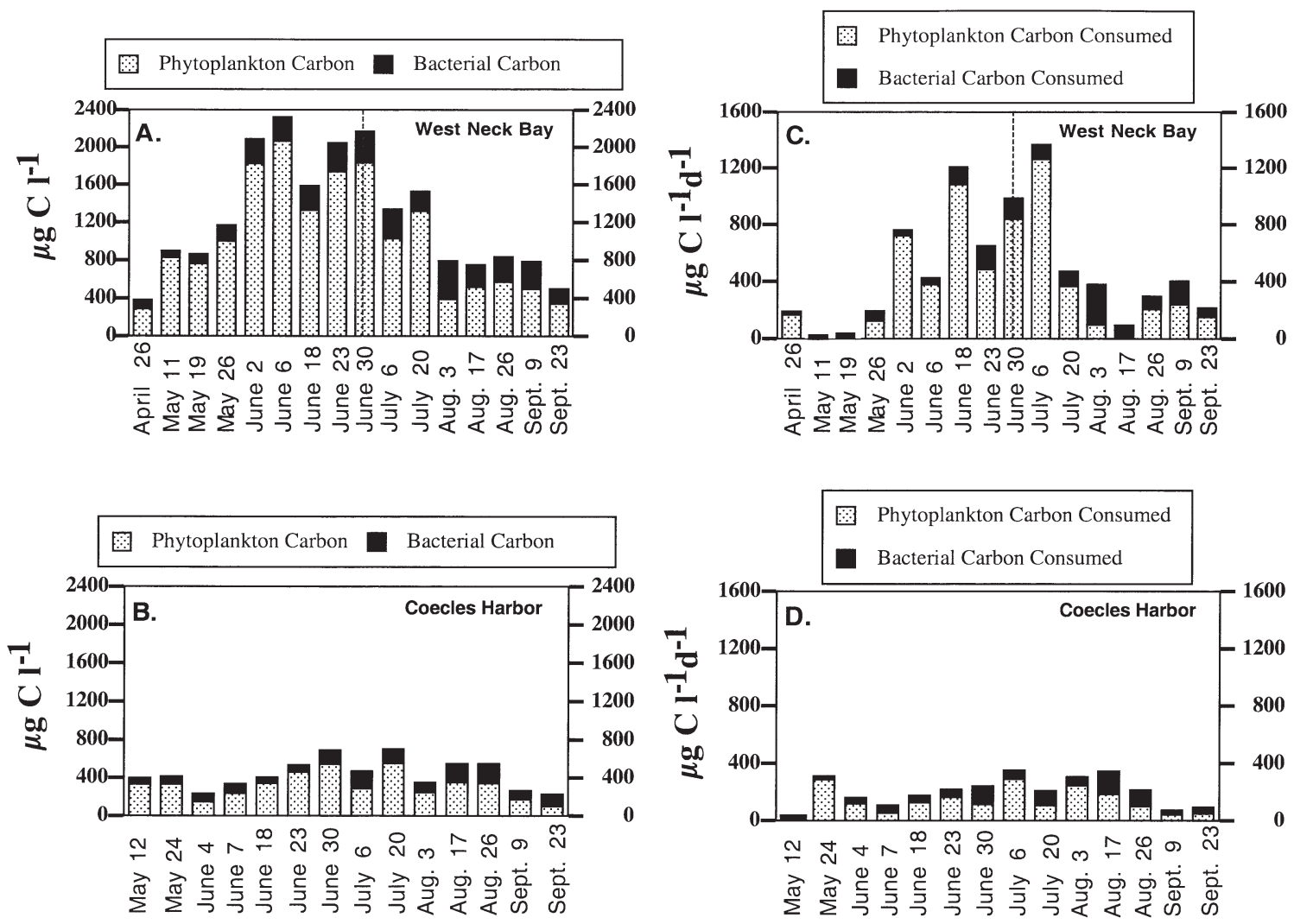

Fig. 9. Phytoplankton and bacterial carbon standing stocks on the dates when herbivory and bacterivory experiments were conducted in (A) West Neck Bay and (B) Coecles Harbor during 1998. Phytoplankton carbon was estimated from chlorophyll (chl) concentration and assuming a C:chl ratio of 60 . Bacterial carbon was estimated from cell number and assuming a carbon content of $20 \mathrm{fg} \mathrm{C} \mathrm{Cell}^{-1}$. Daily removal rates of phytoplankton and bacterial carbon are shown for the dates when herbivory and bacterivory experiments were conducted in (C) West Neck Bay and (D) Coecles Harbor. Removal rates are based on standing stocks $(A, B)$ and mortality rates (Tables 1 to 4$)$. The vertical dashed line in $(A)$ and $(C)$ indicates the sampling date with the highest observed abundance of Aureococcus anophagefferens

\section{Carbon flow}

Ratios of bacterial biomass to phytoplankton biomass in WNB and $\mathrm{CH}$ indicated that bacteria were an important reservoir of living carbon in these ecosystems. Average bacterial carbon was $31 \%$ of phytoplankton carbon in WNB and $45 \%$ of phytoplankton carbon in $\mathrm{CH}$ (Fig. 9A,B). Ratios of bacterial carbon to phytoplankton carbon ranged from 0.08 to 1.01 in WNB and 0.19 to 1.28 in $\mathrm{CH}$. The ratio of bacterial carbon to phytoplankton carbon increased slightly during the latter half of the summer in both bays, indicating a slight shift toward a more heterotrophic pelagic food web during the mid- to late summer.

Calculations of carbon consumption (herbivory and bacterivory) revealed that bacterivory constituted an important aspect of carbon flux through the microbial community in both bays (Fig. 9C,D). Carbon flux in WNB ranged from undetectable (i.e., slopes of regressions not significantly different from 0 ) to $1260 \mu \mathrm{g} \mathrm{Cl}^{-1}$ $\mathrm{d}^{-1}$ due to grazing on phytoplankton (overall average of 471), while carbon flux due to bacterivory ranged from 24 to $281 \mu \mathrm{g} \mathrm{Cl}^{-1} \mathrm{~d}^{-1}$ (overall average of 99). Thus, average carbon flux due to bacterivory in this bay was approximately $21 \%$ of the carbon flux due to herbivory. The percentage of energy flux due to bacterial grazing increased in August and September as phytoplankton biomass dropped (Fig. 9C). Carbon flux in $\mathrm{CH}$ ranged from undetectable to $291 \mathrm{\mu g} \mathrm{Cl}^{-1} \mathrm{~d}^{-1}$ (overall average of 146) due to herbivory and from 17 to $162 \mu \mathrm{g} \mathrm{C}^{-1} \mathrm{~d}^{-1}$ (overall average of 68) due to bacterivory. Average carbon flux due to bacterivory was approximately $47 \%$ of the flux due to herbivory, indicating that bacterivory was proportionally more important to energy flow in this bay relative to WNB (Fig. 9D). These comparisons are, of course, dependent on the specific conversion factors used to obtain phytoplankton carbon from chlorophyll concentration ( $\mathrm{C}: \mathrm{chl}=60)$ and bacterial carbon from cell number $\left(20 \mathrm{fg} \mathrm{cell}^{-1}\right)$. Nevertheless, our concurrent measure- 
ments of microbial herbivory and bacterivory provide a means of directly comparing carbon flow via the consumption of phytoplankton and bacteria. A direct comparison of these trophic activities has rarely been reported.

In summary, carbon flux due to herbivory and bacterivory by microbial consumers was high in both the WNB and $\mathrm{CH}$ ecosystems in the present study. Our experimental results demonstrated that substantial percentages of phytoplankton and bacterial standing stocks were consumed by phagotrophic protists in these bays. These protistan grazers presumably form an important trophic link between these prey assemblages and the metazoan zooplankton. Reports of significant grazing on ciliates by larger zooplankton in Long Island bays support the hypothesis that a major fraction of phytoplankton and bacterial production is transferred to higher trophic levels via nano- and microzooplanktonic consumers (Lonsdale et al. 1996).

Acknowledgements. We gratefully acknowledge the assistance of Rebecca Schaffner, Dawn Moran, Mark Dennett, Sean Wilson and Mike Doall for field and laboratory assistance. St. Gabrielle's Youth House provided access to $\mathrm{CH}_{\text {; }}$ Mrs Katherine Black and Mrs Margaret Wilson provided access to WNB. Dr Donald Anderson provided antibody for the immunological identification and counting of Aureococcus anophagefferens. This study was supported by NY Sea Grant BTRI Project R/CE-12.

\section{LITERATURE CITED}

Andersen RA, Saunders GW, Paskind MP, Sexton JP (1993) Ultrastructure and 18S rRNA gene sequence for Pelagomonas calceolata gen. et sp. nov. and the description of a new algal class, the Pelagophyceae classis nov. J Phycol 29:701-715

Anderson DM, Kulis DM, Cosper EM (1989) Immunofluorescent detection of the brown tide organism Aureococcus anophagefferens. In: Cosper EM, Bricelj VM, Carpenter EJ (eds) Novel phytoplankton blooms: causes and impacts of recurrent brown tides and other unusual blooms, Vol 35. Springer-Verlag, Berlin, p 265-294

Bartram WB (1980) Experimental development of a model for the feeding of neritic copepods on phytoplankton. J Plankton Res 3:25-51

Bricelj WM, Lonsdale DJ (1997) Aureococcus anophagefferens: causes and ecological consequences of mid-Atlantic 'brown tides'. Limnol Oceanogr 42:1023-1038

Bruno SF, Staker RD, Sharma GM (1980) Dynamics of phytoplankton productivity in the Peconic Bay estuary, Long Island. Est Coast Mar Sci 10:247-263

Burkill PH, Mantoura RFC, Llewellyn CA, Owens NJP (1987) Microzooplankton grazing and selectivity of phytoplankton in coastal waters. Mar Biol 93:581-590

Campbell L, Carpenter EJ (1986) Estimating the grazing pressure of heterotrophic nanoplankton on Synechococcus spp. using the sea water dilution and selective inhibitor techniques. Mar Ecol Prog Ser 33:121-129

Caron DA (1983) Technique for enumeration of heterotrophic and phototrophic nanoplankton, using epifluorescence microscopy, and comparison with other procedures. Appl Environ Microbiol 46:491-498

Caron DA, Lim EL, Kunze H, Cosper EM, Anderson DM (1989) Trophic interactions between nano- and microzooplankton and the 'Brown Tide'. In: Cosper EM, Bricelj VM, Carpenter EJ (eds) Novel phytoplankton blooms: causes and impacts of recurrent brown tides and other unusual blooms, Vol 35. Springer-Verlag, Berlin, p 265-294

Caron DA, Dam HG, Kremer P, Lessard EJ and 6 others (1995) The contribution of microorganisms to particulate carbon and nitrogen in surface waters of the Sargasso Sea near Bermuda. Deep-Sea Res 42:943-972

Caron DA, Peele ER, Lim EL, Dennett MR (1999) Picoplankton and nanoplankton and their trophic coupling in surface waters of the Sargasso Sea south of Bermuda. Limnol Oceanogr 44:259-272

Coffin RB, Sharp JH (1987) Microbial trophodynamics in the Delaware estuary. Mar Ecol Prog Ser 41:253-266

Cole JJ, Findlay S, Pace ML (1988) Bacterial production in fresh and saltwater ecosystems: a cross-system overview. Mar Ecol Prog Ser 43:1-10

Cosper EM, Dennison WC, Carpenter EJ, Bricelj VM, and 4 others (1987) Recurrent and persistent brown tide blooms perturb coastal marine ecosystem. Estuaries 10:284-290

Cosper EL, Carpenter ES, Cottrell M (1989) Primary productivity and growth dynamics of the 'brown tide' in Long Island embayments. In: Cosper EL, Bricelj VM, Carpenter ES (eds) Novel phytoplankton blooms: causes and impacts of recurrent brown tides and other unusual blooms, Vol 35. Springer-Verlag, New York, p 139-158

Dagg MJ (1995) Ingestion of phytoplankton by the micro- and mesozooplankton communities in a productive subtropical estuary. J Plankton Res 17:845-857

del Giorgio PA, Bird DF, Prairie YT, Planas D (1996) Flow cytometric determination of bacterial abundance in lake plankton with the green nucleic acid stain SYTO 13. Limnol Oceanogr 41:783-789

Dolan JR, Simek K (1997) Processing of ingested matter in Strombidium sulcatum, a marine ciliate (Oligotrichida). Limnol Oceanogr 42:393-397

Ducklow H (1983) Production and fate of bacteria in the oceans. Bioscience 33:494-501

Ducklow HW, Carlson CA (1992) Oceanic bacterial production. Adv Microb Ecol 12:113-181

Fenchel T (1982) Ecology of heterotrophic microflagellates. IV. Quantitative occurrence and importance as bacterial consumers. Mar Ecol Prog Ser 9:35-42

Gainey LF Jr, Shumay SE (1991) The physiological effect of Aureococcus anophagefferens ('brown tide') on the lateral cilia of bivalve mollusks. Biol Bull 181:298-306

Gallegos CL (1989) Microzooplankton grazing on phytoplankton in the Rhode River, Maryland: nonlinear feeding kinetics. Mar Ecol Prog Ser 57:23-33

Gifford DJ (1988) Impact of grazing microzooplankton in the northwest arm of Halifax Harbour, Nova Scotia. Mar Ecol Prog Ser 47:249-258

González JM, Sherr EB, Sherr BF (1990) Size-selective grazing on bacteria by natural assemblages of estuarine flagellates and ciliates. Appl Environ Microbiol 56:583-589

Guillard RRL (1975) Culture of phytoplankton for feeding marine invertebrates. In: Smith WL, Chanley MH (eds) Culture of marine invertebrate animals. Plenum Publishing, New York, p 29-60

Hardy CD (1976) A preliminary description of the Peconic Bay Estuary. Special Report No 3. The Marine Sciences Research Center, State University of New York at Stony Brook. Reference 76-4 
Kim WS (1993) Zooplankton community effects on the phytoplankton community in Long Island bays. PhD thesis, State University of New York at Stony Brook

Landry MR, Hassett RP (1982) Estimating the grazing impact of marine micro-zooplankton. Mar Biol 67:283-288

Landry MR, Lehner-Fournier JM, Sundstrom JA, Fagerness VL, Selph KE (1991) Discrimination between living and heat-killed prey by a marine zooflagellate, Paraphysomonas vestita (Stokes). J Exp Mar Biol Ecol 146:139-151

Landry MR, Kirshtein J, Constantinou J (1995) A refined dilution technique for measuring the community grazing impact of microzooplankton, with experimental test in the central equatorial Pacific. Mar Ecol Prog Ser 120:53-63

Lee S, Fuhrman JA (1987) Relationships between biovolume and biomass of naturally derived marine bacterioplankton. Appl Environ Microbiol 53:1298-1303

Lessard EJ (1991) The trophic role of heterotrophic dinoflagellates in diverse marine environments. Mar Microb Food Webs 5:49-58

Lively JS, Kaufman Z, Carpenter EJ (1983) Phytoplankton ecology of a barrier island estuary: Great South Bay, New York. Est Coast Shelf Sci 16:51-68

Lonsdale DJ, Cosper EM, Kim WS, Doall M, Divadeenam A, Jonasdottir SH (1996) Food web interactions in the plankton of Long Island bays, with preliminary observations on brown tide effects. Mar Ecol Prog Ser 134:247-263

Marrasé C, Lim EL, Caron DA (1992) Seasonal and daily changes in bacterivory in a coastal plankton community. Mar Ecol Prog Ser 82:281-289

McManus GB (1995) Phytoplankton abundance and pigment changes during simulated in situ dilution experiments in estuarine waters: possible artifacts caused by algal light adaptations. J Plankton Res 17:1705-1716

McManus GB, Ederington-Cantrell MC (1992) Phytoplankton pigments and growth rates, and microzooplankton grazing in a large temperate estuary. Mar Ecol Prog Ser 87: $77-85$

McManus GB, Fuhrman JA (1988) Control of marine bacterioplankton populations: measurement and significance of grazing. Hydrobiologia 159:51-62

Mehran R (1996) Effects of Aureococcus anophagefferens on microzooplankton grazing and growth rates in the Peconic Bays system, Long Island, NY. Masters thesis, State University of New York at Stony Brook

Milligan AJ, Cosper EM (1997) Growth and photosynthesis of the 'brown tide' microalga Aureococcus anophagefferens in subsaturating constant and fluctuating irradiance. Mar Ecol Prog Ser 153:67-75

Murrell MC, Hollibaugh JT (1998) Microzooplankton grazing in northern San Francisco Bay measured by the dilution method. Aquat Microb Ecol 15:53-63

Nival P, Nival S (1976) Particle retention efficiency of an herbivorous copepod, Acartia clausi (adult and copepodite stages): effects on grazing. Limnol Oceanogr 21:24-38

Nuzzi R (1995) The brown tide: an overview. Brown Tide Summit, October 20-21, 1995, Ronkonkoma, p 13-23

Nuzzi R, Waters R (1989) The spatial and temporal distribution of 'brown tide' in eastern Long Island. In: Cosper EL, Bricelj VM, Carpenter ES (eds) Novel phytoplankton blooms: causes and impacts of recurrent brown tides and other unusual blooms, Vol 35. Springer-Verlag, New York, p 117-138

Reckermann M, Veldhuis MJW (1997) Trophic interactions between picophytoplankton and micro- and nanozooplankton in the western Arabian Sea during the NE Mon-

Editorial responsibility: Robert Sanders,

Philadelphia, Pennsylvania, USA soon 1993. Aquat Microb Ecol 12:263-273

Ruiz A, Franco F, Villate F (1998) Microzooplankton grazing in the Estuary of Mundaka, Spain, and its impact on phytoplankton distribution along the salinity gradient. Aquat Microb Ecol 14:281-288

Ryther JH (1954) The ecology of phytoplankton blooms in Moriches Bay and Great South Bay, Long Island, New York. Biol Bull 106:198-209

Salat J, Marrasé C (1994) Exponential and linear estimations of grazing on bacteria: effects of changes in the proportion of marked cells. Mar Ecol Prog Ser 104:205-209

Sanders RW, Caron DA, Berninger UG (1992) Relationships between bacteria and heterotrohic nanoplankton in marine and fresh water: an inter-ecosystem comparison. Mar Ecol Prog Ser 86:1-14

SCDHS (Suffolk County Department of Health Services) (1988-1989) Brown tide comprehensive assessment and management program summaries. Suffolk County Department of Health Services, Riverhead, NY

Sherr EB, Sherr BF (1993a) Preservation and storage of samples for enumeration of heterotrophic protists. In: Kemp PF, Sherr BF, Sherr EB, Cole JJ (eds) Handbook of methods in aquatic microbial ecology. Lewis Publishers, Boca Raton, FL, p 207-212

Sherr EB, Sherr BF (1993b) Protistan grazing rates via uptake of fluorescently labeled prey. In: Kemp PF, Sherr BF, Sherr EB, Cole JJ (eds) Handbook of methods in aquatic microbial ecology. Lewis Publishers, Boca Raton, FL, p 695-702

Sherr EB, Sherr BF (1994) Bacterivory and herbivory: key roles of phagotrophic protists in pelagic food webs. Microb Ecol 28:223-235

Sherr BF, Sherr EB, Fallon RD (1987) Use of monodispersed, fluorescently labeled bacteria to estimate in situ protozoan bacterivory. Appl Environ Microbiol 53:958-965

Sherr BF, Sherr EB, Rassoulzadegan F (1988) Rates of digestion of bacteria by marine phagotrophic protozoa: temperature dependence. Appl Environ Microbiol 54:1091-1095

Sherr EB, Caron DA, Sherr BF (1993) Staining of heterotrophic protists for visualization via epifluorescence microscopy. In: Kemp PF, Sherr BF, Sherr EB, Cole JJ (eds) Handbook of methods in aquatic microbial ecology. Lewis Publishers, Boca Raton, FL, p 213-227

Simon M, Cho BC, Azam F (1992) Significance of bacterial biomass in lakes and the ocean: comparison to phytoplankton biomass and biogeochemical implications. Mar Ecol Prog Ser 86:103-110

Stoecker DK, Gifford DJ, Putt M (1994) Preservation of marine planktonic ciliates: losses and cell shrinkage during fixation. Mar Ecol Prog Ser 110:293-299

Strickland JD, Parsons TR (1972) A practical handbook of seawater analysis. Bull Fish Res Board Can 167:1-310

Weisse T (1989) The microbial loop in the Red Sea: dynamics of pelagic bacteria and heterotrophic nanoflagellates. Mar Ecol Prog Ser 55:241-250

Weisse $\mathrm{T}$ (1999) Bacterivory in the northwestern Indian Ocean during the intermonsoon period. Deep-Sea Res 46: 795-814

Wikner J, Hagström $\AA$ (1991) Annual study of bacerioplankton community dynamics. Limnol Oceanogr 36:1313-1324

Wikner J, Rassoulzadegan F, Hagström Å (1990) Periodic bacterivore activity balances bacterial growth in the marine environment. Limnol Oceanogr 35:313-324

Wilson R (1995) Aspects of tidal and subtidal flushing within the Peconic Bays Estuary. Brown Tide Summit, October 20-21, 1995, Ronkonkoma, NY, p 53-56

Submitted: April 25, 2001; Accepted: September 6, 2001

Proofs received from author(s): November 7, 2001 